ROCZNIKI HISTORYCZNE

Rocznik LXXXII — 2016

MARCIN STARZYŃSKI (Uniwersytet Jagielloński, Kraków)

\title{
Collegium desertum - niedokończona fundacja uniwersytecka Kazimierza Wielkiego
}

Pamięci Profesor Zofii Kozłowskiej-Budkowej (1893-1986)

$w$ trzydziestą rocznice śmierci

\begin{abstract}
Zarys treści: Artykuł przedstawia dyskusję nad lokalizacją pierwszej stałej siedziby Uniwersytetu Krakowskiego, której budowę zaczęto jeszcze za życia króla Kazimierza Wielkiego w mieście Kazimierz przy Krakowie. Właściwe miejsce autor wskazuje na podstawie analizy niewykorzystywanych dotąd źródeł. Fundację wiąże z zainspirowaną powstaniem Collegium Carolinum w Pradze próbą zmiany modelu organizacyjnego uniwersytetu (z oparciem go na beneficjach kościelnych). Realizację przerwała śmierć króla w 1370 r.
\end{abstract}

Content outline: The paper discusses the localisation of the first permanent seat of Cracow University, the building of which was started during the lifetime of King Kazimierz the Great in the town of Kazimierz near Cracow. The exact place is identified by the author on the basis of the sources which were not used for this purpose before. The foundation is connected by the author to the attempt - inspired by the foundation of Collegium Carolinum in Prague of changing the organisational model of the university (linking it to church benefices). The realisation of the project was interrupted by the death of the king in 1370 .

Słowa kluczowe: Uniwersytet Krakowski, kolegia uniwersyteckie, Kazimierz Wielki, Polska XIV w.

Keywords: Cracow University, university colleges, Kazimierz the Great, $14^{\text {th }}$ century Poland

W maju 2014 r. upłynęło sześćset pięćdziesiąt lat od założenia w Krakowie Studium Generale. Rocznica ta wydaje się stanowić dobrą okazję do podjęcia próby ponownego spojrzenia na pewne aspekty jego historii, w szczególności zaś tej najdawniejszej, odnoszonej do ostatnich lat życia króla Kazimierza Wielkiego. W przyrastającej stale literaturze poświęconej dziejom Uniwersytetu Krakowskiego sporo miejsca zajmuje kwestia fundacji 1364 r., której osobną monografię, aczkolwiek nie do końca udaną, poświęcił Stanisław Szczur ${ }^{1}$. Zebrane zostały nieliczne przekazy źródłowe doku-

1 S. S z c z u r, Papież Urban V i powstanie Uniwersytetu w Krakowie w 1364 r., Kraków 1999 (gdzie, s. 7-13, zreferowana starsza literatura). Zob. także M. M a rk ow s ki, Uniwersytet Krakowski w kontekście środkowoeuropejskim późnego średniowiecza i wczesnej nowożytności, Olecko 2005 (Episteme 40), s. 43-52, który ograniczył się w zasadzie do omówienia grupy przywilejów fundacyjnych. Spośród głosów krytycznych po ukazaniu się rozprawy S. Szczura najważniejsza jest wypowiedź K. S t o p k i, Głos w dyskusji nad fundacją 
mentujące działalność wszechnicy jeszcze w czasach panowania ostatniego Piasta. Pozwoliły one na: 1) wskazanie imion bakałarzy artium wypromowanych wówczas w Krakowie i tym samym oznaczenie swoistego kręgu popularności młodej uczelni; 2) ustalenie faktu odbywania (niektórych?) zajęć na wzgórzu zamkowym (in castro Cracoviensi) oraz 3) odnotowanie znanego jedynie z późnego szesnastowiecznego regestu polecenia monarchy skierowanego do władz Krakowa i Kazimierza w 1369 r., by te przetrzymywały schwytanych żaków, którzy włóczyliby się nocą po ulicach tychże miast, lecz przekazywały ich nazajutrz przed oblicze sądu rektorskiego ${ }^{2}$. Nadal powracają jednak pytania wypływające z lektury dwóch podstawowych dla naszego zagadnienia źródeł: znanego fragmentu Annales Jana Długosza o fundacji Uniwersytetu (pod 1361 r.) „w mieście Kazimierzu, w należącej do kapituły wsi Bawół - - koło muru miejskiego, w miejscu obszernym i rozległym, rozciągającym się na tysiąc i więcej kroków we wszystkie strony, [gdzie stanąć miały - M.S.] wspaniałe domy, izby i lektoria oraz wiele przybudówek na mieszkania dla doktorów i magistrów wspomnianego, nowego uniwersytetu"s, oraz bazującego na nim Macieja

Uniwersytetu w Krakowie, Rocznik Krakowski 71, 2005, s. 31-40, który, jak się wydaje, wyczerpując temat, w przekonujący sposób wyjaśnił, iż Kazimierz Wielki „w świetle terminologii średniowiecznej, stosującej się do tworzenia instytucji kościelnych, nie stał się - ostatecznie fundatorem" (s. 39). W tym kontekście zastanawia celowość nowszych publikacji: obszernej (354 ss.) rozprawy autorstwa J. S o nd la, Przywileje fundacyjne Uniwersytetu Jagiellońskiego oraz przywilej nadania szlachectwa jego profesorom (z historyczno-prawnym komentarzem), Kraków 2015, w której autor przedrukował tłumaczenia najstarszych dokumentów uniwersyteckich przygotowane przez Stanisława Krzyżanowskiego w 1900 r., zaopatrując je w pozbawiony przypisów komentarz (np. rozdział II: Uniwersytet prawniczy Kazimierza Wielkiego, s. 21-136), czy artykułu W. U r u s z c z a k a, Powstanie Uniwersytetu w Krakowie w 1364 roku, Czasopismo-Prawno Historyczne 64, 2014, s. 14-39, w którym z kolei autor, polemizując z ustaleniami S. Szczura, w ogóle nie odniósł się do propozycji K. Stopki. O obecności fundacji Kazimierzowskiej w pamięci Uniwersytetu zob. M. Z d a n e k, Uniwersytet Krakowski wobec własnej przeszłości w XV i na początku XVI wieku. Stan i perspektywy badań, w: Felix indiget amicis. Studia z dziejów kultury duchowej i intelektualnej średniowiecza ofiarowane Profesorowi Krzysztofowi Ożogowi, Kraków 2016, s. 340-341.

2 Zespół źródeł potwierdzających owe fakty nie zmienił się od czasu Z. K o z ł o w s k i e j - B u d k o w e j: La fondation de l'Université de Cracovie, en 1364, et son rôle dans le développement de la civilisation en Pologne, w: Les Universités Européennes du XIV ${ }^{\mathrm{e}}$ au XVIII ${ }^{\mathrm{e}}$ Siècle. Aspects et Problèmes, Genève 1967, s. 13-25 (przedruk w języku polskim: Założenie Uniwersytetu w Krakowie w roku 1364 i jego rola w rozwoju kultury w Polsce, w: taż, Studia z dziejów kultury średniowiecznego Krakowa, Kraków 2015 [Biblioteka Krakowska 161], s. 152-171); W sprawie Uniwersytetu Kazimierzowskiego (przegląd nowych ustaleń, dyskusji i hipotez), Studia Historyczne 12, 1969, s. 237-247 (przedruk w: Studia, s. 180-195).

${ }^{3}$ Ioannis Dlugossi Annales seu cronicae incliti Regni Poloniae, lib. IX, Varsaviae 1978, s. 307: in opido Kazimiriensi, ab eo circa Cracouiensem civitatem in villa capitulari vocata Bauol studium generale secus murum in loco amplo et spatioso ad mille et amplius passus in omnes partes se protendente, domosque pulcherrimas, cameras, lectoria et plurimas officinas ex lapideo muro pro cohabitatione doctorum et magistrorum dicte nove universitatis pulcherrimo opera edificat. Chronologicznie starszy (pod względem czasu zredagowania), ale niestety dużo bardziej ogólny, jest fragment opisu wsi Bawół pomieszczony przez Długosza w Liber beneficiorum, w którym kronikarz podał, iż w mieście Kazimierzu założonym w 1335 r. król studio generali illic fundando nobilitare decreverat locumque pro collegiis muris fabricaverat (Joannis Długosz Liber beneficiorum dioecesis Cracoviensis, t. I = Opera omnia, t. VII, 
z Miechowa, który uzupełnił starszy przekaz o założeniu wszechnicy informacją, iż przeznaczone dla niej miejsce znajdowało się nie tylko przy murze miejskim, ale i w pobliżu kościoła św. Wawrzyńca (secus murum et ecclesiam sancti Laurencii), a król Jan Olbracht osadził w 1494 r. krakowskich Żydów, ubi cellae pro collegio et lectoriis per Kazimirum secundum regem Poloniae extructae fuerant ${ }^{4}$. Pytania te można natomiast sformułować w sposób następujący: 1) gdzie dokładnie w tym przykrakowskim ośrodku stanęły wzmiankowane przez Długosza i Miechowitę budowle uniwersyteckie?, 2) kiedy król zaczął je tam wznosić? Na żadne z nich nie odpowiedziano do dziś w sposób jednoznaczny. Kolejne podjęcie się takiej próby nie będzie jednak możliwe bez dokładnego wglądu w starszą literaturę i bez prześledzenia sposobów interpretowania nieznacznie tylko uzupełnianego w ciągu lat zespołu źródeł.

U genezy nowożytnej, jeszcze bezkrytycznej dyskusji nad lokalizacją gmachów czy też gmachu uniwersyteckiego w Kazimierzu należałoby umieścić Marcina Radymińskiego (1602-1664), profesora filozofii w Uniwersytecie Krakowskim oraz autora nigdy nieukończonej syntezy dziejów Almae Matris ${ }^{5}$. W swoich rocznikach (Annales Almae Academiae Cracoviensis, 1658) wyłożył on zupełnie nową koncepcję genezy Uniwersytetu, wedle której król Kazimierz, fundując Studium w 1347 r. (sic), wykładających prawo umieścił w nowo wybudowanych gmachach, które Radymiński, za Długoszem, lokalizował właśnie w Kazimierzu. Nie wiadomo natomiast, na jakiej podstawie dodał do Długoszowych słów drobny z pozoru szczegół, iż budynki znajdowały się sub muro versus orientem, a zatem we wschodniej części miasta. Dopiero w 1400 r. katedry z Kazimierza miały zostać przeniesione do Krakowa, a w wymyślonym przez autora orszaku kroczącym w dniu uroczystego otwarcia Uniwersytetu z zamku na ulicę Świętej Anny za królem postępowali smutni mieszczanie kazimierscy. Fragmenty tej pracy, aczkolwiek znane w środowisku uniwersyteckim,

Cracoviae 1863, s. 173). Dla porządku można dodać, iż w Rocznikach znajdują się jeszcze dwie lakoniczne wzmianki o założeniu Studium w Kazimierzu, jedna przy opisie śmierci i dokonań królowej Jadwigi (Annales, lib. X, Varsaviae 1985, s. 232: hec studium generale a Kazimiro secundo Polonie rege in oppido Kazimiriensi fundari ceptum, instauravit), druga zaś przy opisie założenia Kolegiów Artystów i Kanonistów (tamże, s. 240: Quod etsi dudum per Kazimirum secundum Polonie regem orditum fuerit et collegium muro in Casimiria erectum, non tamen consumatum).

${ }^{4}$ Matthias de Miechów, Chronica Polonorvm, Craccouiae: Hieronymus Vietor 1521 (reprint: Kraków 1986), s. CCXLII, CCCXLIX. Na przekazie Miechowity, pisząc o założeniu Uniwersytetu (1361!), oparł się także siedemnastowieczny kazimierski kronikarz klasztorny Stefan Ranatowicz (1617-1694) ze zgromadzenia kanoników regularnych laterańskich. Autor ten znał również Roczniki Długosza, które wykorzystał w opisie rządów prepozyta Andrzeja, kiedy czyniono starania o fundację kartuzji (1478), zob. Casimiriae civitatis, urbi Cracouiensi confrontatae, origo, Kraków, Biblioteka Jagiellońska, rps 3742 III, k. 5v, 17r.; K. Ł a t a k CRL, Ksiądz Stefan Ranatowicz (1617-1694). Barokowy kronikarz i pisarz klasztorny, Kraków 2010, s. 171-218. Tradycję tę utrwalił następnie Józef Putanowicz (1737-1788), profesor filozofii i teologii Uniwersytetu Krakowskiego oraz reformator Wydziału Filozoficznego, w memoriale opracowanym na potrzeby Komisji Edukacji Narodowej: Stan wewnętrzny y zewnętrzny Studii Generalis Universitatis Cracoviensis, [Kraków] 1774, s. 1; zob. także: W. B a c z k o w s k a, Putanowicz Józef, w: Polski słownik biograficzny (dalej cyt.: PSB), t. XXIX, 1986, s. 459-462.

${ }^{5}$ H. B a ry c z, Radymiński Marcin, w: PSB XXX (1987), s. 32-36. 
zostały upublicznione szerszemu gronu czytelników dopiero w połowie XIX w. ${ }^{6}$ W podobnym tonie wypowiadał się także Jerzy Samuel Bandtkie (1768-1835), historyk i językoznawca, który w 1811 r. objął kierownictwo Biblioteki Jagiellońskiej’. Opisując w 1835 r. dzieje panowania Władysława Jagiełły, podał informację (niepopartą niestety żadnym odwołaniem), iż ,założył król hojnie nadane w Krakowie kollegia, i wskrzesił na nowo podupadłe nauki. Gmachy [Uniwersytetu - przyp. M.S] spustoszone na Kazimierzu oddane były Żydom na pomieszkanie ich, stąd tam teraz miasto żydowskie i bożnica ich sławna"' ${ }^{\text {". }} \mathrm{Z}$ tekstu Bandtkiego nie wynika jednak bezspornie, czy stało się to właśnie w czasie rządów Jagiełły.

Powyższe ustalenia znane były oczywiście Józefowi Muczkowskiemu (1795-1858), językoznawcy, podobnie jak Bandtkie wykładowcy bibliografii na Uniwersytecie Jagiellońskim, który jako pierwszy krytycznie spojrzał na dawniejsze przekazy źródłowe? W 1847 r. przedstawił on obszerną pracę poświęconą założeniu Studium Generale, do opracowania której skłoniły go przede wszystkim dość znaczne rozbieżności odnośnie do roku jego powstania ${ }^{10}$. Analizując przekaz Długosza, umieszczony jak wiadomo pod 1361 r., napotkał oczywiście informację o gmachach uniwersyteckich w Kazimierzu. Powątpiewał jednak w prawdomówność dziejopisa, skoro „w lat 39 później Jagiełło, otwierając szkołę, nowe domy dla niej zakupił przy ulicy Ś. Anny w Krakowie, kiedy ukończenie rozpoczętych, jeżeli tak dalece były wybudowane, jak Długosz wspomina, mniejszych kosztów wymagało". Argumentował przy tym dalej, choć nieco naiwnie: „Ale twierdzenie tego dziejopisa o wzniesieniu tych gmachów zbija szczególniej ta okoliczność, iż nieukończone kazimierskie budowle na inny użytek obrócone być mogły, a tak musiałby ich ślad w przyszłości pozostać: boć murowane gmachy wieki trwają" ". Muczkowski znał oczywiście dalszą część przekazu Długosza o fundacji kartuzji, odnoszącą się do 1478 r., ale i ta go nie przekonała,

${ }^{6}$ Ustępy z Radymińskiego Annalium Almae Academiae Cracoviensis Centuria prima i z początku drugiéj do dziejów założenia Uniwersytetu odnoszące się, J. M u c z k o w s ki, Wiadomość o założeniu Uniwersytetu Krakowskiego, Rocznik Towarzystwa Naukowego Krakowskiego z Uniwersytetem Jagiellońskim Złączonego 19, 1849, s. 234 (professores legum - - Casimiriam in aedes amplissimas, recenter a se exstructas transfert), 238-239. Wykład Radymińskiego przejął z kolei do swoich rozważań Józef S o ł ty k o w i c z (17621831), prawnik i wykładowca Szkoły Głównej Krakowskiej: O stanie Akademii Krakowskiej od założenia jej w roku 1347, aż do teraźniejszego czasu, krótki wykład historyczny, Kraków 1810, s. 96-97, przyp. 3; zob. H. We re s z y c ka, E. Orman-Micht a, Sołtykowicz (Sołtykiewicz) Józef, w: PSB XL (2000-2001), s. 437-441 (wzmiankowana wyżej praca jest znacznie poszerzonym tekstem wystąpienia Sołtykowicza przed księciem Fryderykiem Augustem goszczącym w Krakowie w 1810 r.).

${ }^{7}$ A. U 1 j a s z, Jerzy Samuel Bandtkie (1768-1835). Uczony, pedagog i pracownik książki polskiej, Annales Universitatis Paedagogicae Cracoviensis 104, 2011 (Studia ad Bibliothecarum Scientiam Pertinentia 9), s. 41-51.

8 J. S. B a n d t k i e, Dzieje narodu polskiego, t. II, Wrocław 1835, s. 16. Nową próbę datacji kazimierskiej Starej Synagogi na okres po 1407 r. przedstawił ostatnio D. N i e m i e c, Średniowieczna geneza Starej Synagogi z krakowskiego Kazimierza, w: Ostoja tradycji. Katalog wystawy, Kraków 2016, s. 15-48.

9 J. Kra s, B. Ło p u s z ań s k i, Muczkowski Józef, w: PSB XXII (1977), s. 246-250.

10 J. Muczk ow ski, Wiadomość, s. 149-251.

11 Tamże, s. 165-166. 
pisał bowiem: „w 117 lat po wzniesieniu gmachów przez Kazimierza W. ani śladu domów i ogrodów nie było. Może być, że zaczątek budowy akademii kazimierskiej uległ takiemu losowi, jak rozpoczęta za dni naszych (r. 1835) na wielki rozmiar budowa głównego szpitala przy ulicy Wesołej, która się na założeniu fundamentów skończyła" "12. Udało się natomiast Muczkowskiemu zupełnie trzeźwo (a patrząc z perspektywy ponad półtora stulecia, zaskakująco trafnie) spojrzeć na kwestię fundacji Uniwersytetu (,Kazimierz W. wydał wprawdzie w r. 1364 przywilej na cząstkowe jego utworzenie, to jest na wydział filozoficzny i prawny, ale to chwalebne postanowienie w zupełności do skutku nie przyszło, a w części rozwinięte, z czasem upadło"13), ale z kwestią lokalizacji budynków wszechnicy w mieście Kazimierzu poradzić już sobie nie potrafił.

Nie upłynęło jednak wiele czasu, gdy problem powrócił, i to ze zdwojoną siłą. W roku jubileuszu pięćsetlecia fundacji Uniwersytetu (1864), choć z racji panujących wówczas warunków politycznych pozbawionego charakteru publicznego ${ }^{14}$, w Towarzystwie Naukowym Krakowskim powzięto decyzję, by odnaleźć relikty gmachów uniwersyteckich w Kazimierzu. Uderzono oczywiście w tony patriotyczne, całe przedsięwzięcie traktując jako powinność wobec narodu polskiego oraz jego tożsamości. Władysław Łuszczkiewicz (1828-1900), historyk sztuki-samouk i ceniony malarz, kierujący wówczas Szkołą Sztuk Pięknych ${ }^{15}$, pisał w 1866 r.: ,jakże nie poszanować wiekowej rocznicy dzieła, dokonanego dla podniesienia światła w narodzie, nie uczcić miejsca, z którego wychodzili przewodnicy w czci Bożej i radzie kraju”16. „Wszakże dlatego, że zaginęła tradycja właściwego miejsca gmachów, być może, że ich pozostałości nie uderzające ani malowniczością, ani stylem, mogą się gdzieś ukrywać wpośród ciasnych a licznych ulic oddalonych od miasta"17. W Towarzystwie Naukowym powołano zatem specjalną Komisję, której kierownictwo objął Paweł Popiel ${ }^{18}$. Zanim jednak poznano wyniki jej prac, ukazało się studium Józefa Łepkowskiego (1826-1894), wiceprzewodniczącego tego zespołu, a zarazem twórcy krakowskiej archeologii i pioniera w zakresie prac nad inwentaryzacją zabytków architektury ${ }^{19}$.

12 Tamże, s. 167.

13 Tamże, s. 185.

${ }^{14}$ Wedle przekazanych z Wiednia wytycznych uroczystości te „nie powinny mieć wydźwięku narodowego i nie mogły odbierać uczelni miana uniwersytetu austriackiego". O przygotowaniach i obchodach: U. P e r k o w s k a, Jubileusze Uniwersytetu Jagiellońskiego, Kraków 2000 (Biblioteka Krakowska 140), s. 43-83, cyt. s. 58.

${ }_{15}$ M. R z e p iń s k a, Na styku pedagogiki i historii sztuki. Ze studiów na Władysławem Łuszczkiewiczem, w: Symbolae historiae artium. Studia z historii sztuki Lechowi Kalinowskiemu dedykowane, Warszawa 1986, s. 493-506.

${ }^{16}$ W. Łu s z c z k i e w i c z, Sprawozdanie z wypadku poszukiwań Komissji, wyznaczonej z grona Towarzystwa Nauk. Krak. celem odszukania miejsca i zabytków budowlanych Uniwersytetu założonego przez Kazimierza Wielkiego, Rocznik Towarzystwa Naukowego Krakowskiego 34, 1866, s. 95-112, cyt. ze s. 95.

17 Tamże, s. 97.

18 Odnośnie do działalności Komisji zob. J. Duży k, A. Tre i d e r ow a, Zagadnienie opieki nad zabytkami w działalności Towarzystwa Naukowego Krakowskiego, Rocznik Biblioteki Polskiej Akademii Nauk w Krakowie 3, 1957 (druk: 1959), s. 218-219.

${ }_{19}$ M. G e d 1, Józef Łepkowski (1826-1894), w: Uniwersytet Jagielloński. Złota księga Wydziału Historycznego, Kraków 2000, s. 32-37. 
Posiłkując się znanym przekazem Długosza, badacz ów postanowił „wśród nędzy i ubóstwa miejsce dawnych budowli akademickich zaznaczyć" ${ }^{20}$ na terenie dawnej wsi Bawół, włączonej do przykrakowskiego Kazimierza jeszcze przed połową XIV w. i stanowiącej jego północno-wschodnią częśćc ${ }^{21}$, gdzie „na trzy lata przed datą przywileju [król] rozpoczął budowę potrzebnych gmachów"22. Miały one wznosić się ,przy murze w miejscu obszernem i rozległem, przeszło tysiąc kroków wzdłuż i wszerz wynoszącym”. Tradycja tego miejsca musiała być niewątpliwie żywa jeszcze w końcu lat siedemdziesiątych XV w., skoro Długosz planował wznieść tam klasztor kartuzów, ale zamiary te pokrzyżowali kazimierscy mieszczanie, bezprawnie zajmując opustoszały teren ${ }^{23}$. Znał nadto Łepkowski ogłoszony drukiem po raz pierwszy w $1861 \mathrm{r}$. dyplom fundacyjny kartuzji kazimierskiej wystawiony przez Kazimierza Jagiellończyka 10 IX 1477 r., mocą którego monarcha przekazywał pod jej budowę teren w mieście Kazimierzu, ubi quondam clarissimus Casimirus tertius rex studium generale fabrica murali fundandum duxerat, wraz z całą zalegającą tamże kamienną materią, pozostałą $\mathrm{w}$ izbach starożytnego kolegium (damus et omnem materiam lapidum in praefati vetusti collegii cameris existentem $)^{24}$. Tenor tego dokumentu pozwala zatem na stwierdzenie, że stały tam wówczas bliżej nieokreślone pozostałości dawnego gmachu uniwersyteckiego, stanowiące najpewniej pierwszą jego kondygnację z zachowanymi jeszcze wewnątrz izbami (pomieszczeniami), w których zalegał budulec. Nie wiadomo jednak niestety dokładnie, gdzie gmach ten się znajdował. Odpowiedzi na to pytanie szukał Łepkowski w dokumencie z $9 \mathrm{~V}$ 1480 r., poświadczającym zakup przez Jana Długosza i braci kartuzów, Michała i Zygmunta z klasztoru w austriackim Gaming, wsi Balice na potrzeby klasztoru tej reguły in collibus sancti Stanislai iuxta Istulam ${ }^{25}$. Łepkowski nie dysponował niestety odpowiednią wiedzą odnośnie do dziejów Długoszowej fundacji kartuskiej, którą właśnie w 1480 r. postanowiono ulokować w podkrakowskiej, położonej częściowo na wzgórzach, wsi Bielany ${ }^{26}$. Wzgórza te Długosz, przejawiający specjalną atencję dla świętego biskupa, zaczął nazywać, lub przynajmniej upowszechniać ich nazywanie, ,wzgórzami świętego Stanisława” (nazwa ta pojawia się bowiem tylko

${ }^{20}$ J. Łe p k ow s ki, O zabytkach Kruszwicy, Gniezna i Krakowa oraz Trzemeszna, Rogoźna, Kcyni, Dobieszewka, Gołańczy, Żnina, Gąsawy, Pakości, Kościelca, Inowrocławia, Strzelna i Mogilna sprawozdania i studia, Kraków 1866, zwł. rozdz. IX: Starożytne budowle i zakłady naukowe Uniwersytetu Jagiellońskiego z powodu pamiątki pięćsetletniego jubileuszu Akademii krakowskiej w r. 1864, s. 259-272, cyt. ze s. 265.

${ }^{21}$ F. S i k o r a, Bawół, w: Słownik historyczno-geograficzny województwa krakowskiego w średniowieczu, cz. I, z. 1, Wrocław 1980, s. 28.

22 J. Ł e p k o w s k i, O zabytkach, s. 263. Dodać można, iż autor ten bezkrytycznie (może za Radymińskim?) wskazywał, że „uczono na Bawole prawa i filozofii” (tamże, s. 263).

23 Tamże, s. 265.

${ }^{24}$ Tamże, s. 268. Dyplom ten po raz pierwszy opublikowano we fragmentach w broszurze sygnowanej B. S. [w rzeczywistości autorstwa Teofila Ż e braw s ki e g o], Rozbiór pisma Józefa Łepkowskiego pod tytułem: Przegląd zabytków przeszłości w okolicach Krakowa, Bochnia 1861, s. 9-11; zob. także: K. E s tr e i c h e r, Bibliografia polska XIX stólecia, t. V, Kraków 1880, s. 320.

${ }^{25}$ J. Łe e p k o w s ki, O zabytkach, s. 269; B. S., Rozbiór, s. 11.

${ }^{26}$ F. S i k o r a, Bielany, w: Słownik historyczno-geograficzny województwa krakowskiego, cz. I, z. 1, s. 91-93. 
w kilku dyplomach związanych z uposażeniem kartuzji). Próbował w ten sposób, jak dowodził Franciszek Sikora, ,uczynić z górujących nad Krakowem wzgórz bielańskich miejsce jakiegoś kultu tego świętego"27. Podążając za tym tropem, Łepkowski domyślał się, że Kazimierzowskie budowle uniwersyteckie stanęły „,nad Wisłą, na jej pobrzeżnych pagórkach", a zatem we wschodniej części miasta ${ }^{28}$. Wspomniał przy tym o znanej propozycji wyrażonej jeszcze przez J. S. Bandtkiego, ,że stara bożnica żydowska z tej akademii powstała", oraz o miejscowej, aczkolwiek zupełniej bezzasadnej tradycji, uważającej jeden z domów przy ulicy Szerokiej (219/69 w gminie X) „za szczątek Kazimierzowskiej budowli”29 (zob. rys. 1, nr VI). Chcąc jednak operować twardymi dowodami, sięgnął Łepkowski do przekazu Macieja z Miechowa, który w swojej kronice, wydanej drukiem po raz pierwszy w 1519 r., uzupełnił przekaz Długosza o założeniu Uniwersytetu znaną informacją o kościele św. Wawrzyńca ${ }^{30}$. „Stała tedy Kazimierzowska akademia obok kościoła ś. Wawrzyńca opodal murów warownych, od strony Wisły, na rozległym placu" ${ }^{31}$. Ten zdawałoby się ostrożny wniosek osłabiał jednak dalszy wywód Łepkowskiego: „Nie gdzieindziej tedy, ale za tym kościołem, ku klasztorowi Bożego Ciała, podwalin akademickich szukać należy. Wedle tych bowiem wskazówek wznosiło się Kazimierzowskie collegium tam gdzie dziś ogrodzenie do kanoników laterańskich podobno należące, w gminie VI, liczbą 313/137 zaznaczone - -, bo tam szczęty warownych murów istnieją"32. Szczególnej roli nabierał w tym wnioskowaniu mur oddzielający miasto żydowskie od chrześcijańskiego (zob. rys. 1, Mur od Żydów), gdyż ,wiek XIV pewno nie gdzieindziej, tylko przy kościele szkołę zakładał, tem bardziej, że w czasach fanatyzmu trzeba się było od Żydów przedzielić" ${ }^{33}$.

Z lektury tekstu W. Łuszczkiewicza, ogłoszonego drukiem również w 1866 r., ale już po zakończeniu prac Komisji ${ }^{34}$, nie wynika bynajmniej, że znał on referowane wyżej ustalenia. Bazował natomiast na tym samym zespole źródeł pisanych, chociaż miejscami nie potrafił ich zinterpretować ${ }^{35}$. Początkowo sam zwrócił uwagę na dwie kamienice, które wedle miejscowej (żydowskiej) tradycji (co interesujące, wywołanej

${ }^{27}$ Te n ż e, O fundacji kartuskiej Jana Długosza, Kwartalnik Historyczny 80, 1973, s. 881884, cyt. ze s. 884 . Nowszą literaturę zbiera R. W it k o w s k i, Praedicare manibus. Zakon Kartuzów w Europie Środkowej od początku XIV do połowy XVI wieku, Salzburg 2011 (Analecta Cartusiana 285/2), s. 1223-1242, faktycznie jednak bazując na ustaleniach F. Sikory.

${ }^{28}$ J. Łe e p k ow ski, O zabytkach, s. 269.

${ }^{29}$ Tamże, s. 269-270.

30 Tamże, s. 270.

31 Tamże, s. 271.

32 Tamże.

33 Tamże, s. 272.

${ }^{34}$ Wyniki prac (najpewniej wstępne) przedstawiane były na posiedzeniu Towarzystwa już 5 V 1865 r., zob. D. R e d e row a, K. S t a c how s k a, Ośrodek naukowy krakowski w świetle materiałów Towarzystwa Naukowego Krakowskiego 1841-1871. Wybór źródeł, Rocznik Biblioteki Polskiej Akademii Nauk w Krakowie 2, 1956 (druk: 1959), s. 163, nr 211.

35 Nieco pokrętnie próbował np. uzgodnić przekaz Długosza z tenorem dokumentu z maja 1364 r., ,że to co się dziać miało na Kazimierzu, uważano za należące do samego Krakowa”, zob. W. Ł u s z c z k i e w i c z, Sprawozdanie, s. 99. Z kolei fragment kroniki Miechowity (Chronica, s. CCCXLIX) o przeniesieniu przez króla Jana Olbrachta Żydów z Krakowa do Kazimierza błędnie umieścił pod 1490 r. Rozpatrywał go zaś przede wszystkim w kontekście istnienia 
wśród mieszkańców powracającymi pytaniami uczonych!) miały powstać z resztek budowli akademickich (zob. rys. 1, nr V-VI). Podobnie jak Łepkowski, odstąpił od lokalizacji gmachów Kazimierzowskich na terenie zajmowanym przez Starą Synagogę, której powstanie odniósł do początku XV w. Proponował wreszcie, by poszukiwania zacieśnić „,do placów i ogrodów po za bożnicą starą ku Wiśle i rynkowi głównemu Kazimierza, dziś ulicą Gazową, ulicą Śgo Wawrzyńca i murem dawnym fortecznym ograniczoną" "36. Liczył oczywiście Długoszowe tysiąc kroków, ale liczbę tę rozumiał, jako pięćset wzdłuż i pięćset wszerz ${ }^{37}$. Co więcej, ulokowanie frontów budowli akademickich badacz ten widział, z racji porozrzucanych tamże węgarów z epoki ostrołuku, przy ulicy Gazowej (zob. rys. 1, nr II-III) ${ }^{38}$.

Co zatem udało się ustalić Komisji? „Udało się jej oznaczyć obszerny plac, gdzie stać musiały te budowle. Plac ten zamkniętym jest ulicami Śgo Wawrzyńca i Gazową, murem miejskim od zakładu gazowego ponad brzegiem Wisły aż do muru z r. 1627 biegnącym, na koniec od północy sąsiadujący z żydowskiem miastem i bożnicą starą" (zob. rys. 2) ${ }^{39}$. Na przyszłość W. Łuszczkiewicz postulował przeprowadzenie badań archeologicznych oraz archiwalnych (,,w regestrach wydatków miasta i księgach cechowych"40), którym to pomysłem zdecydowanie wyprzedzał zresztą swoją epokę. Dodać można, iż drugi z wyrażonych wówczas postulatów nie został w pełni zrealizowany do chwili obecnej. Pierwsze poszukiwanie przyniosło więc ,tylko słaby odblask światła"41.

W opozycji do ustaleń Komisji stanął Eustachy Ekielski (1804-1870), prawnik z wykształcenia i praktykujący w Krakowie adwokat ${ }^{42}$, który w 1867 r. napisał, a dwa lata później ogłosił drukiem obszerną rozprawę, będącą pierwszą próbą monograficznego ujęcia dziejów miasta Kazimierza, opartą jednak na wyrywkowej kwerendzie w materiale rękopiśmiennym, niewielkim dostępnym wówczas materiale drukowanym oraz domysłach autora ${ }^{43}$. Nie uciekał przy tym od dość radykalnie formułowanych opinii względem ludności żydowskiej ${ }^{44}$. Są one widoczne również

wówczas w Kazimierzu synagogi, wnioskując, że ta nie mogła stanąć na terenie, na którym wznosiły się zabudowania uniwersyteckie (s. 110-111).

36 W. Łus z c z k i e w i c z, Sprawozdanie, s. 103.

37 Tamże, s. 111.

38 Tamże, s. 108-109.

39 Tamże, s. 111.

40 Tamże, s. 112.

41 Tamże.

${ }^{42}$ M. Ty r o w i c z, Ekielski Eustachy Wojciech, w: PSB VI (1948), s. 219-220.

${ }^{43}$ E. E ki e ls ki, Miasto Kazimierz i budowle akademickie w tem mieście, Kraków 1869.

${ }^{44}$ Np. tamże, s. 109: „Niepotrzebne będą: Polski Uniwersytet i inne naukowe zakłady, bo już i dziś niebaczni i nienauczeni doświadczeniem, ścielą drogę do zniszczenia polskiego Uniwersytetu, chcąc przeprowadzić wybór profesora na jedną z katedr medycyny Żyda, jakby już dla braku utalentowanych Polaków, profesorów koniecznie między Żydami szukać potrzeba". W ten niewybredny sposób komentował Ekielski zapewne uzyskanie w 1869 r. stanowiska docenta prywatnego przez Józefa Oettingera, który w 10 lat później otrzymał w Uniwersytecie tytuł profesora, zob. R. W. Gry g lew s ki, Józef Oettinger (1818-1895), w: Uczeni żydowskiego pochodzenia we współczesnych dziejach Uniwersytetu Jagiellońskiego, Kraków 2014, s. 163-170. 
W osobnym rozdziale poświęconym zaginionym budowlom uniwersyteckim ${ }^{45}$. Znając drukowane sprawozdanie z prac Komisji, zanegował ogłoszone tam wyniki niemalże w całości. Zastanawiał się np., jak można było w ogóle brać pod uwagę miejscową (żydowską) tradycję: ,i dziś spytajmy się, nie już o budowle Akademii, ale o rzecz, o której każdy Żyd najdokładniejszą ma wiadomość, jeżeli tylko ztąd zysku spodziewać się nie może, odpowie, że nie wie, lub wymijającą da odpowiedź"46. Ekielski uważał zatem, że „Komisja na fałszywym stanąwszy gruncie, miejsca budowli ani samych budowli, wskazać nie mogła"47. Sam nie błyszczał jednak zanadto erudycją, przypuszczając, że nie ma nawet pewności, „czyli Kazimierz W. miasto Kazimierz założył"48. Prowadził przy tym swój wywód tak, by przeforsować tezę, iż w średniowieczu nie było w mieście Kazimierzu wydzielonego terenu zamieszkanego tylko przez Żydów. Zdarzyło mu się przy okazji wypaczyć znaczenie przywoływanego już przekazu Macieja z Miechowa, jakoby przeniesieni przez Jana Olbrachta Żydzi mieli w Kazimierzu zamieszkać „,pod murem kościoła św. Wawrzyńca”49. Jako pierwszy zwrócił natomiast uwagę, że Długoszowe tysiąc kroków, którymi odmierzono teren pod budynki uniwersyteckie, to właściwie licentia poetica kronikarza, skoro „cała długość miasta Kazimierza od bramy Glinianej do Wielickiej, mierzy nie więcej niż 700 kroków" "50. Próbując zaś odszukać pozostałości Kazimierzowskich gmachów, wsparł się na użytym przez Długosza przymiotniku pulcherrimus. Budowle te miały być bowiem przede wszystkim piękne. Ekielski znalazł je w mieście żydowskim, w kwartale wyznaczanym ulicami Kierków (obecnie Jakuba) oraz Żydowską (obecnie przedłużenie ulicy Józefa w kierunku Szerokiej). Wskazywał zatem dom narożny (oznaczony wówczas numerem 266/90; zob. rys 1, nr I) zlokalizowany właśnie u zbiegu ulic Kierków i Józefa (posiadający narożnik wzmocniony ciosanym kamieniem wapiennym) oraz na sąsiadującą z nim Synagogę Nową (właściwie Wysoką, wówczas numer 267/89, zob. rys. 1, nr 4), z pomieszczoną na piętrze salą modlitwy oraz wspierającymi fasadę szkarpami. Dowodził, że „,dom nr. 266/90 ozdobnie był kiedyś zbudowany, sięga odległych czasów, a może i Kazimierza W. Bóżnica Nowa mogła być częścią gmachów Akademii, jak równie sklepione izby w tyłach tych domów mogły być owymi oficynami. Niezwykła wysokość okien i grubość murów, sklepienia, domniemywać każą, że to były budowle niepospolitego przeznaczenia, budowle wiele dawniejsze od budowli drewnianych żydowskich, i zbliżałyby się do opisanych przez Długosza" ${ }^{51}$. Opisane na kartach Annales budynki miały więc według Ekielskiego wznosić się na niezabudowanym w XIV w. placu, znajdującym się po lewej stronie u wylotu ówczesnej ulicy Sukienniczej (obecnie Józefa), rzeczywiście położonym w niewielkiej odległości od muru miejskiego i kościoła św. Wawrzyńca. O ile jednak samo usytuowanie gmachów uniwersyteckich w topografii miasta, zaproponowane przez tego badacza, mogło wydawać się interesujące, jako

\footnotetext{
${ }^{45}$ E. E k i e ls k i, Miasto, rozdz. V: Budowle Akademii na Kazimierzu, s. 112-130.

46 Tamże, s. 117.

47 Tamże, s. 122.

48 Tamże.

49 Tamże, s. 124.

50 Tamże.

51 Tamże, s. 128.
} 
zupełnie przeciwstawne w stosunku do ustaleń Łepkowskiego i Łuszczkiewicza, o tyle doszukiwanie się ich reliktów w dwóch wyróżniających się architektonicznie budynkach (w tym nowożytnej, jak dziś wiadomo, synagodze ${ }^{52}$ ), nie poparte znajomością rudymentów historii architektury, zaprowadziło autora na manowce. Dodać w tym miejscu można, że Ekielski natrafił na wydrukowane w 1703 r. w Drukarni Akademickiej dziełko księdza Andrzeja Stanisława Buchowskiego Gloria Domini poświęcone dziejom kościoła św. Anny, w którym znajduje się wyjątkowy plan Krakowa i Kazimierza, zawierający oznaczenie miejsca lokalizacji gmachów uniwersyteckich w Kazimierzu (rys. 3) ${ }^{53}$. Autor zamieścił co prawda jego przerys, ale niestety niezbyt dokładny. Miejsce Studium $z$ czasów Kazimierza Wielkiego zostało bowiem oznaczone, zgodnie z koncepcją Ekielskiego, w północno-wschodniej części Kazimierza, niemalże w centrum miasta żydowskiego.

W 1872 r. ukazała się pierwsza, obszerna monografia poświęcona założeniu Uniwersytetu w Krakowie, pióra znakomitego latynisty Alfreda Brandowskiego $(1835-1888)^{54}$. Bazując na tym samym co poprzednicy zespole wzmianek źródłowych, zaproponował, że asumpt do budowy gmachów uniwersyteckich w Kazimierzu w 1361 r. dała ostra zima w roku poprzednim, a król chciał w ten sposób dać zatrudnienie ubogim ${ }^{55}$. Wskazywał nadto, że budynek Studium stanął jedynie do wysokości sklepionych piwnic, skoro w jego miejscu, zgodnie z autorską interpretacją przekazu Długosza, mieszczanie wznieśli potem domy i założyli ogrody. Należy wyjaśnić, że użyty przez Długosza w Annales przymiotnik vacuus (w zwrocie: locus vacuus domibus et hortis), według Brandowskiego, nie opisywał bynajmniej pustego terenu bez domów i ogrodów, ale miejsce nieposiadające właściciela ${ }^{56}$. Stąd też znany z dokumentu Kazimierza Jagiellończyka rzeczownik camera, którym określano części owego gmachu, czy raczej jego pozostałości (vetustum collegium), autor utożsamił z występującym u pisarzy starożytnych określeniem hipogea concamerata (sklepiona piwnica) ${ }^{57}$. Sądził także, iż budowa została przerwana przed 1364 r. z uwagi na sprzeciw kurii papieskiej, która ,nie chciała prawdopodobnie - - przystać na wybór tej mieściny, papieże bowiem dbali zawsze o przyzwoitość miejsca, gdzie miał stanąć pałac biskupi, gmach uniwersytecki”"58. Nie pominął oczywiście Brandowski kwestii śladów materialnych po fundacji Kazimierzowskiej. Znając ustalenia Łuszczkiewicza, jak również „bałamuctwa i fałsze” Ekielskiego,

${ }^{52}$ Zob. B. Kra s n ow ols k i, Bożnica Wysoka na krakowskim Kazimierzu, Krzysztofory. Zeszyty Naukowe Muzeum Historycznego Miasta Krakowa 21, 2002, s. 35-46 (tam starsza literatura).

${ }^{53}$ A. S. B u c h ow s k i, Gloria Domini, Cracoviae: Typis Academicis 1703, plan na k. 4r (foliacja własna); zob. K. E s tr e i c h e r, Bibliografia polska, t. XIII, Kraków 1894, s. 415.

${ }^{54}$ A. B r a n d o w s k i, Założenie Uniwersytetu Krakowskiego w roku 1364 na podstawie dyplomatycznej, Kraków 1872; zob. W. O g r o d z i ń s k i, Brandowski Roch Alfred, w: PSB II (1936), s. 386.

${ }_{55}$ A. B r a n d o w s k i, Założenie, s. 133, przyp.: „Mniemam, że i ta klęska -- dała pochop królowi do stawiania gmachów - - i że przy tej właśnie sposobności zaczął król w roku 1361 budować gmach uniwersytecki”.

56 Tamże, s. 141-143, przyp.

57 Tamże, s. 137, przyp.

58 Tamże, s. 138, przyp. 
postanowił zwrócić się do sekretarza Komisji powołanej niegdyś w Towarzystwie Naukowym Krakowskim z pytaniem o jej aktywność po 1866 r. Z publikowanego $\mathrm{w}$ tej pracy listu Łuszczkiewicza do Brandowskiego wynika, iż nie mając odpowiednich funduszy, Komisja zawiesiła swoją działalność. W 1867 r. na terenie przy murze miejskim, w pobliżu miejsca, gdzie stał niegdyś kościół św. Wawrzyńca, rozpoczęto wydobywanie gliny. Łuszczkiewicz bacznie obserwował postępujące tam prace, które niestety nie ujawniły pozostałości jakichkolwiek budynków. W roku następnym brat Władysława, Antoni Łuszczkiewicz, kierując budową kanału biegnącego od kościoła Bożego Ciała w stronę Wisły, niespodziewanie natrafił w południowo-wschodnim narożu dawnego kazimierskiego rynku (placu Wolnica), u zbiegu ulic Pustej (obecnie Bocheńskiej) i Mostowej, na pozostałości grubych murów (zob. rys. 4). W. Łuszczkiewicz nie miał wątpliwości, że należy je utożsamić z gmachem z fundacji króla Kazimierza. „Mury te należą do piwnic sklepionych, - ale wyżej pociągnionemi nie były, albowiem śladu nie noszą szczerb jakowych, ale pozostały na tej szychcie kamienia, na której już cegła wychodzącego z ziemi gmachu leżeć miała"59. Rewelacyjne rozpoznania poczynione przez braci Łuszczkiewiczów chyba jednak nie do końca zaskoczyły Brandowskiego, który stwierdził, że „,do powyższego wyniku doszedł własną drogą" ${ }^{60}$. Odkrycie z końca lat sześćdziesiątych XIX w. przynosiło zatem zupełnie nową lokalizację gmachu uniwersyteckiego z czasów Kazimierza Wielkiego - teoretycznie nadal w zgodzie ze starszymi wytycznymi, czyli w pobliżu muru miejskiego i kościoła św. Wawrzyńca, ale faktycznie w narożu rynku (czego jednak już nie zaakcentowano), w bardzo eksponowanym miejscu, w prestiżowej przestrzeni miasta, w pobliżu fary oraz budynku ratusza (zob. rys. 5). Trzy dekady później, 7 VI 1900 r., na fasadzie kamienicy narożnej w dawnym rynku (róg placu Wolnica i ulicy Bocheńskiej) wmurowano tablicę z inskrypcją: „W tej części miasta, Bawołem niegdyś zwanej, król Kazimierz Wielki, zakładając w r. 1364 uniwersytet, rozpoczął wznosić dla niego pierwszą siedzibę. Część fundamentów tej nigdy nie dokończonej budowy odnaleziono w roku 1868 podczas przekopywania ulicy" ${ }^{\text {"61. }}$ W. Łuszczkiewicz tego wydarzenia jednak nie dożył. Zmarł 23 V $1900 \mathrm{r}$.

W roku jubileuszu pięćsetlecia odnowienia Uniwersytetu przez Władysława Jagiełłę ${ }^{62}$ i wmurowania wspomnianej wyżej tablicy ukazał się jeden z najlepszych w całej dotychczasowej historiografii okołouniwersyteckiej tekstów traktujący o fundacji 1364 r. Jego autor, Stanisław Krzyżanowski (1865-1917), jeden z twórców nowoczesnych badań dyplomatycznych i, co należy podkreślić, pierwszy historyk, który zabrał głos w dyskusji nad powstaniem Studium Generale w Krakowie ${ }^{63}$, nie wypowiedział się co prawda względem lokalizacji gmachu kolegium w mieście Kazimierzu, ale w swojej rozprawie umieścił jeden z najcenniejszych z dzisiejszego punktu widzenia wniosków, iż „od hospicjów mógł król przechodzić do kolegium,

59 Tamże, s. 260-262, przyp.

${ }^{60}$ Tamże, s. 262, przyp.

${ }^{61}$ Tekst napisu za: J. D ą b r o w s k i, Czy Uniwersytet Kazimierzowski działał na Kazimierzu?, Rocznik Biblioteki Polskiej Akademii Nauk w Krakowie 5, 1959 (druk: 1961), s. 60.

${ }^{62}$ U. P e r k o w s k a, Jubileusze, s. 117-175.

${ }^{63}$ B. W y r o z u m s k a, Stanisław Krzyżanowski (1865-1917), w: Mediewiści, Poznań 2011, s. 151-160. 
ale nigdy odwrotnie" ${ }^{\prime 4}$. Dla porządku należy wyjaśnić, iż model Studium nakreślony w dokumencie monarszym z $12 \mathrm{~V} 1364$ r. stanowi umiejętne połączenie nie tylko bolońskiego i padewskiego wzorca szkoły wyższej, ale także neapolitańskiego. Z Bolonii zapożyczono m.in. innymi system hospicjów, czyli izb mieszkalnych (kwater) wynajmowanych przez mieszczan zarówno wykładowcom, jak i słuchaczom ${ }^{65}$. Nie zgłębiając bardziej tego zagadnienia, S. Krzyżanowski konkludował, że „uniwersytet na Bawole - - jest dalszą fazą w rozwoju myśli Kazimierza" ${ }^{66}$.

U progu XX stulecia o lokalizacji gmachu uniwersyteckiego w Kazimierzu wypowiedział się jeszcze Stanisław Tomkowicz (1850-1933), ceniony inwentaryzator zabytków Galicji ${ }^{67}$. Znając doskonale ustalenia poprzedników, dodał do nich nowy, interesujący szczegół źródłowy odnośnie do tradycji gruntów uniwersyteckich w Kazimierzu. Przywołał mianowicie treść ugody zawartej między kahałem kazimierskim a władzami uniwersyteckimi w 1752 r. (oblatowanej w aktach grodzkich krakowskich w 1774 r.), dotyczącej uiszczania przez gminę żydowską pewnej daniny w naturaliach (korzeniach) na rzecz Uniwersytetu ,za miejsca i osiadłości swoje na Kazimierzu, niegdyś przesławnej Akademii Krak. od Kazimierza II nadane i własne, a potem przez tę synagogę za króla Jana Albrachta posiadłe"68. Opierając się na przekazie znanego już planu Kazimierza z pracy księdza A. Buchowskiego, jak również wnioskując, iż osadzonych w 1494 r. w mieście Żydów „może przy tem obdarowano - - sąsiednim spornym placem pouniwersyteckim", stwierdzał, że „,zagarnięte place pouniwersyteckie oczywiście musiały leżeć po stronie żydowskiej na północ od granicy. Co najwyżej część ich, może przez żydów nie zajęta, mogła rozciągać się na południe od linii granicznej, a więc ulicy ś. Wawrzyńca" (zob. rys. 6) ${ }^{69}$. „Terytorium Kazimierzowskich budowli przesunąć należy - pisał Tomkowicz - cokolwiek na północ od miejsca oznaczonego przez Łuszczkiewicza, a więc w okolicę placu Bawół, po obu stronach wschodniej części ul. ś. Wawrzyńca" "70. Tomkowicz postanowił nadto poddać weryfikacji dawniejsze ustalenia W. Łuszczkiewicza związane z odkryciem pozostałości gotyckich budynków w narożu dawnego rynku kazimierskiego. Na przełomie września i października 1901 r. przeprowadził sondażowe poszukiwania przed kamienicą, na ścianie której wmurowano

${ }^{64}$ S. K r z y ża n o w s k i, Poselstwo Kazimierza Wielkiego do Awinionu i pierwsze uniwersyteckie przywileje, Rocznik Krakowski 4, 1900, s. 1-111, cyt. ze s. 39.

${ }^{65}$ Zob. J. Wy r o z u m s k i, Uniwersytet Krakowski a Uniwersytet Boloński, w: tenże, Z najstarszych dziejów Uniwersytetu Krakowskiego. Szkice, Kraków 1996, s. 23-24 (wcześniej ten tekst ukazał się w języku włoskim: L'università bolognese e lo Studio generale cracoviano di Casimiro il Grande, w: Commentationes historicae Almae Matri Studiorum Bononiensi novem saecula feliciter celebranti ab Universitate Jagellonica Cracoviensi oblatae, Kraków 1988, s. 59-67).

${ }^{66}$ S. Kr z y ża n o w s k i, Poselstwo, s. 39.

67 J. R e m e r, Stanisław Tomkowicz. Sylweta konserwatora, Ochrona Zabytków Sztuki 1, 1930-1931, s. 34-51.

${ }^{68}$ S. To m k o w i c z, Ślady Uniwersytetu Kazimierzowskiego?, Rocznik Krakowski 5, 1902, s. 183-195, cyt. ze s. 188. Informację o tym przekazie autor otrzymał od Stanisława Kutrzeby.

${ }^{69}$ Tamże, s. 190.

70 Tamże. 
jubileuszową tablicę. Odsłonił oczywiście fragmenty gotyckich murów, ale także drewniany pomost (fragment przejazdu czy traktu?) przykryty warstwą rzecznego namułu $^{71}$. To ostatnie odkrycie stanie się w przyszłości podstawą do dość karkołomnych hipotez względem dziejów budynków uniwersyteckich w Kazimierzu. Sam Tomkowicz był bardzo ostrożny w formułowaniu wniosków, aczkolwiek nie do końca spójny w swoim dowodzeniu. Pisał bowiem: „w każdym razie zdaje się być pewnem, iż w tem miejscu [to jest w południowo-wschodnim narożu placu Wolnica - M.S.] stały średniowieczne budynki i że były wśród nich izby sklepione. Czy należały one do gmachów uniwersyteckich, zaczętych przez Kazimierza? Na to wiadomości nie dają nam dostatecznej odpowiedzi" "72. Skoro zaś gmachy Kazimierzowskie lokalizował na podstawie źródeł pisanych w innym zupełnie miejscu, w jakim celu poszukiwał ich w obrębie dawnego rynku? Wyrażał natomiast nadzieję, że „kiedyś przybędą nowe badania, które uzupełnią drobne odkrycia roku 1901"73.

Te przybyły dopiero w latach trzydziestych ubiegłego stulecia. W 1932 r. ukazały się drukiem najstarsze miejskie księgi sądowe z XIV w. W opublikowanym materiale z lat 1369-1402 słowo collegium nie padło niestety ani $\mathrm{razu}^{74}$. Ujawniła je dopiero Wanda Konieczna, prowadząc kwerendę w materiale rękopiśmiennym z początku XV w. W pracy o najstarszym okresie w historii miasta Kazimierza (do 1419 r.), przygotowanej na seminarium Jana Dąbrowskiego i wydanej drukiem w 1938 r., podała informacje o budynku uniwersyteckim (a nie o gmachach), wydobyte z rejestrowanych w księgach rady rachunków miejskich oraz akt ławniczych ${ }^{75}$. Najstarsze z nich pochodziły z 1402 r., kolejne zaś z lat 1405, 1407, 1410 i 1412. We wszystkich collegium występuje jako pewien punkt orientacyjny w topografii miasta. Jednak wypłaty dla osób mieszkających penes albo circa collegium w żaden sposób nie mogły być pomocne dla ustalenia lokalizacji samego gmachu ${ }^{76}$. Bezspornie wsparły natomiast wymowę znanych już przekazów z ostatniej ćwierci XV i początku XVI w. Tego wątku W. Konieczna niestety nie wyakcentowała. W początku XV w. owo kolegium, mijane na co dzień przez mieszkańców Kazimierza, było więc najpewniej budynkiem wznoszącym się ponad powierzchnię ziemi, choć, jak należy mniemać, niedokończonym, a nie jedynie przesklepionymi piwnicami. Istotne jest też samo określenie tego gmachu w kręgu kancelarii miejskiej mianem collegium, na co autorka również nie zwróciła uwagi. Ponad trzy dekady po śmierci króla Kazimierza Wielkiego żyła zatem wciąż tradycja o budowie gmachu uniwersyteckiego. Co więcej, gmach ów realnie istniał jeszcze w przestrzeni miasta. Nie można jednak wykluczyć, że nazwanie go rzeczownikiem collegium było jedynie odbiciem realiów początku

71 Tamże, s. 191-193 (wraz z rysunkami poglądowymi).

72 Tamże, s. 195.

73 Tamże.

${ }^{74}$ Księgi radzieckie kazimierskie 1369-1381 i 1385-1402, wyd. A. Chmiel, Kraków 1932.

75 W. K o n i e c zn a, Początki Kazimierza (do r. 1419), w: Studia nad przedmieściami Krakowa, Kraków 1938 (Biblioteka Krakowska 94), s. 7-90.

76 Tamże, s. 41-43. Autorka wykorzystała jedynie księgę radziecką z lat 1402-1416 (Kraków, Biblioteka Jagiellońska, rps nr 1045/I) oraz księgę ławniczą z lat 1407-1427 (Kraków, Archiwum Narodowe, rps nr K 377), zob. M. S t a r z y ń s k i, Sredniowieczny Kazimierz, jego ustrój i kancelaria, Kraków 2015, s. 53-56, 88-90. 
XV w. - odnowienia Uniwersytetu i fundacji Kolegium Królewskiego, a nie tradycji sięgającej stulecia XIV. Po przyjęciu takiej interpretacji zrozumiały staje się zupełny brak informacji o tym budynku w źródłach miejskich sprzed 1402 r. Być może jest to szczegół mało istotny, ale z materiału zarejestrowanego przez W. Konieczną wynika, iż w drugim dziesięcioleciu XV w. przy określeniu collegium pojawił przymiotnik antiquum. Najpewniej mogło to mieć związek z dynamicznie postępującym rozwojem odnowionego Studium w Krakowie. W sprawie lokalizacji autorka opowiedziała się w zasadzie za propozycją S. Tomkowicza, dodając, że „od kościoła św. Wawrzyńca na południe, w drugiej połowie XIV i na początku XV w. była znaczniejsza niezabudowana przestrzeń, na której mogły się zmieścić okazalsze budowle"77. Te zaś mogły „powstać dopiero po roku 1364, tj. po roku założenia uniwersytetu w Krakowie”78.

Po drugiej wojnie światowej dyskusję nad omawianym tematem wznowił Stefan Świszczowski (1903-1989), absolwent krakowskiej Akademii Sztuk Pięknych i Politechniki Lwowskiej, od połowy lat trzydziestych prowadzący na szeroką skalę prace konserwatorskie przy obiektach zabytkowych ${ }^{79}$. W $1951 \mathrm{r}$. na jednym z ostatnich posiedzeń Polskiej Akademii Umiejętności referował on wyniki swoich ustaleń, opartych na „poszukiwaniach archiwalnych oraz częściowo terenowych”. Pierwsze z wymienionych faktycznie ograniczyły się do lektury źródeł drukowanych oraz opracowań. Na tej podstawie doszedł do wniosku, że „uniwersytet leżący na obszarze wsi Bawół, czyli we wschodniej części Kazimierza, mógł istnieć albo na południe od Psiego Rynku i ulicy św. Wawrzyńca [a zatem tam, gdzie lokalizowali go Łepkowski oraz Łuszczkiewicz - M.S.] albo na północ od niej, a w żadnym wypadku po obu jej stronach [jak sądził Tomkowicz - M.S.], przy czym najprawdopodobniejsze, ze względu na znaczy obszar, byłoby usytuowanie go po stronie północnej" ${ }^{80}$.

Na odpowiedź nie trzeba było długo czekać. Już w 1951 r. głos w tej sprawie zabrał Henryk Barycz (1901-1994), wytrawny znawca dziejów Uniwersytetu, aczkolwiek skupiający się głównie na dobie staropolskiej ${ }^{81}$. Zanegował on propozycje S. Krzyżanowskiego „o rzekomej ewolucji pierwotnego systemu hospicjalnego Uniwersytetu na kolegialny - kościelny"\$2, co jednak nie przeszkodziło mu kilka stron dalej pisać tak o wszczęciu przez Rudolfa IV Habsburga budowy kwartału uniwersyteckiego

${ }^{77}$ W. K o n i e c z n a, Początki, s. 42.

78 Tamże, s. 43.

${ }^{79}$ M. B or ow i j s ka - B i rke n majer ow a, Stefan Świszczowski (1903-1989), Ochrona Zabytków 43, 1990, s. 98-99.

${ }^{80}$ S. Ś w i s z c z o w s k i, Uniwersytet Kazimierza Wielkiego w Kazimierzu, Sprawozdania z Czynności i Posiedzeń Polskiej Akademii Umiejętności 52, 1951, nr 2, s. 80-84, cyt. ze s. 83. Ustalenia te podtrzymał w późniejszej pracy (Miasto żydowskie na Kazimierzu w świetle nowych badań, Biuletyn Krakowski 2, 1960, s. 48) oraz w popularnej monografii miasta (Miasto Kazimierz od Krakowem, Kraków 1981, s. 87-101), wskazując na zidentyfikowane przez siebie w kamienicach przy ulicy Szerokiej fragmenty murów gotyckich, ale powstrzymując się jednocześnie od identyfikowania ich z pozostałościami gmachów uniwersyteckich.

${ }^{81}$ K. S t o p k a, Henryk Barycz jako dziejopis Akademii Krakowskiej, w: Henryk Barycz 1901-1994, W Służbie Nauki, nr 9, Kraków 2004, s. 37-50.

${ }^{82}$ H. B a r y c z, Z zagadek Uniwersytetu Kazimierzowskiego w Krakowie, Sprawozdania z Czynności i Posiedzeń Polskiej Akademii Umiejętności 52, 1951, nr 9, s. 841-844; t e n ż e, Z zagadek Uniwersytetu Kazimierzowskiego w Krakowie, Przegląd Zachodni 8, 1952, s. 113125 , cyt. ze s. 114 . Ustalenia te H. Barycz powtórzył następnie w szkicu: Trudne początki 
w Wiedniu w 1365, jak i o fundacji oraz otwarciu w Pradze w 1366 r. przez Karola IV pierwszej stałej siedziby tamtejszego Uniwersytetu, czyli Collegium Carolinum $^{83}$. $\mathrm{Na}$ podstawie kolofonu z rękopisu Biblioteki Jagiellońskiej nr 2032, znanego już Kazimierzowi Morawskiemu ${ }^{84}$, mylnie dowodził, że „na zamku wawelskim mieścił się fakultet artystów a najprawdopodobniej także prawnicze studium" ${ }^{85}$. Uzupełnił natomiast znany dotąd zespół źródeł wyświetlających najstarsze dzieje Uniwersytetu o dwa interesujące przekazy. Odnalazł ustawę porządkową z końca XVIII w., dotyczącą studentów Uniwersytetu, którzy gromadnie udawali się do Kazimierza na odpust w dniu św. Wawrzyńca (10 sierpnia), dopuszczając się w tym czasie różnych drobnych wykroczeń. Wedle Barycza, ów zwyczaj „o głębszym znaczeniu”, mający zapewne dość odległą metrykę, w wyraźny sposób akcentował dawne sąsiedztwo kwartału uniwersyteckiego w Kazimierzu z kościołem św. Wawrzyńca ${ }^{86}$. Nie mniej istotne było również odkrycie przez tego autora w rękopisie Biblioteki Jagiellońskiej nr 5574, mieszczącym inwentarz archiwum uniwersyteckiego z 1586 r., regestu zaginionego dziś dokumentu z 1369 r., mocą którego Kazimierz Wielki nakazywał władzom komunalnym Krakowa i Kazimierza, by studentów włóczących się nocą, a zatrzymanych przez służby miejskie, odprowadzać przed sąd rektora ${ }^{87}$. H. Barycz przypuszczał, że „pierwotne ognisko uniwersyteckie, mieszczące się w samym mieście Krakowie, objęło najwyraźniej również Kazimierz, i że tam niewątpliwie już została położona jakaś uniwersytecka komórka nauczania" "88. Takie wnioskowanie nie wydaje się jednak do końca uprawnione, a tym bardziej w kontekście innych mandatów królewskich kierowanych do władz miast tworzących krakowską aglomerację. Odnaleźć można je w wielkim przywileju dla Krakowa z 7 XII 1358, ale i w dyplomie dla Uniwersytetu z 12 V 1364 r. W pierwszym mowa jest o karze banicji, która, jeśli przestępstwo zostało popełnione w Krakowie, rozciągała się również na Kazimierz oraz Florencję (wówczas jeszcze przedmieście) i vice versa ${ }^{89}$. Z kolei według jednego z postanowień przywileju uniwersyteckiego student osądzony przez rektora ma być wypędzony tak z Krakowa, jak i z Kazimierza ${ }^{90}$. Dyplom z 1369 r. stanowił też dla Barycza argument w polemice ze S. Krzyżanowskim, gdyż „mógł wyróść tylko w systemie hospicjalnym", co więcej, odnotowane w nim stanowisko wicerektora charakterystyczne było dla tego właśnie modelu organizacyjnego szkoły wyższej ${ }^{91}$. Cenna była propozycja wyjaśnienia użytej przez Długosza nazwy kolegium, która miała być po prostu przeniesieniem stosunków piętnastowiecznych do poprzedniego

(Rzecz o Uniwersytecie Kazimierzowskim), w: t e n ż e, Alma Mater Jagellonica. Studia i szkice z przeszłości Uniwersytetu Krakowskiego, Kraków 1958, s. 11-38.

${ }^{83}$ H. B a r y c z, Z zagadek, s. 120-121.

${ }^{84}$ K. M or a w s k i, Historia Uniwersytetu Jagiellońskiego. Średnie wieki i Odrodzenie ze wstępem o Uniwersytecie Kazimierza Wielkiego, t. I, Kraków 1900, s. 43.

${ }^{85}$ H. B a r y c z, Z zagadek, s. 119.

86 Tamże, s. 121.

87 Tamże, s. 122 (tam także tekst regestu w języku łacińskim i przekładzie na język polski).

88 Tamże.

${ }^{89}$ Przywileje ustanawiające gminy miejskie wielkiego Krakowa (XIII-XVIII wiek), opr.

B. Wyrozumska, Kraków 2007, s. 34 (i w przekładzie na język polski, s. 60).

${ }_{90}$ Najstarsze przywileje, s. 21 (i w przekładzie na język polski, s. 25).

${ }^{91}$ H. B a r y c z, Z zagadek, s. 124. 
stulecia $^{92}$. W konkluzji Barycz stwierdzał, że „od roku być może 1366, pod wpływem Karola IV przystąpił król do budowy osobnej dzielnicy uniwersyteckiej na Kazimierzu, wybierając przestrzeń między kościołem św. Wawrzyńca a murami miejskimi”"93.

Pierwszy w tej dyskusji od czasów S. Krzyżanowskiego głos mediewisty należał do Jana Dąbrowskiego (1890-1965) ${ }^{94}$. W pisanym w końcu lat pięćdziesiątych artykule krakowski historyk postanowił zrekapitulować dotychczasowe ustalenia ${ }^{95}$. W umiejętny sposób sprostował domniemania H. Barycza „o głębszym znaczeniu” pielgrzymek studenckich, łącząc je z kwestią ściągania znanej już od czasów publikacji S. Tomkowicza daniny w naturaliach od kahału kazimierskiego $0^{96}$. Nie wiedzieć jednak czemu, uznał za miarodajną dawną wypowiedź Klemensa Bąkowskiego, jakoby budowę gmachów na Kazimierzu przerwał wylew Wisły już w 1358 r. ${ }^{97}$ Przyznając także trafność identyfikacji murów odkrytych w narożu placu Wolnica i nieznacznie korygując wypowiedź Bąkowskiego, dowodził, że „pomiędzy rokiem 1367-1370 nastąpiła katastrofalna dla kolegium powódź" ${ }^{98}$. Pogląd ten zastanawia tym bardziej, że wiślanych namułów nie znaleziono bynajmniej na odkrytych pod ziemią gotyckich murach. J. Dąbrowski odrzucił przy tym świadectwo znanego z druku planu A. Buchowskiego z oznaczeniem locum primaevae Universitatis. Zasadnie skorygował za to interpretację regestu z 1369 r. (używając zresztą przywołanych wyżej argumentów). Zwrócił też uwagę na pomijany dotąd przekaz norymberczyka Hartmanna Schedla (1440-1514), który w swoim Liber chronicarum, wydanym drukiem w 1493 r., odnotował w Kazimierzu clarissima monumenta vetusti collegii, ufundowanego przez królową Jadwigę ${ }^{99}$. W podsumowaniu stwierdził, że tak naprawdę nie ustalono dotąd nic pewnego (,nie mamy żadnych danych na to, by Uniwersytet Krakowski działał kiedykolwiek na Kazimierzu”), poza tym, że „wznoszone na Kazimierzu tzw. Collegium zostało zatopione przez wylew Wisły i że z tego powodu budowa jego została przerwana" ${ }^{100}$.

Do dyskusji nad powstaniem Uniwersytetu w Krakowie włączył się również wytrawny historyk prawa Adam Vetulani (1901-1976) ${ }^{101}$, który od połowy lat sześćdziesiątych publikował mniejsze prace poświęcone fundacji Studium Generale w 1364 r. ${ }^{102}$ Ich wyniki zostały następnie powtórzone w osobnej

92 Tamże.

93 Tamże.

${ }^{44}$ K. B a c z k o w s k i, Jan Dąbrowski (1890-1965), w: Uniwersytet Jagielloński (jak w przyp. 17), s. 324-333.

95 J. D ą b row s k i, Czy Uniwersytet, s. 53-72.

96 Tamże, s. 57, 69-72 (edycja wzmiankowanej umowy).

${ }^{97}$ K. B ą k o w s k i, Dawne kierunki rzek pod Krakowem, Rocznik Krakowski 5, 1902 , s. 147.

98 J. D ą b r o w s k i, Czy Uniwersytet, s. 62.

${ }^{99}$ H. Schedel, Liber chronicarum, Nürnberg: Anton Koberger 1493, trzecia nienumerowana karta recto $\mathrm{w}$ druku po k. CCLXVIr.

100 J. D ą b r o w s k i, Czy Uniwersytet, s. 69.

101 S. P ł a z a, Adam Vetulani - wydawca źródeł oraz badacz ustroju i prawa polskiego, w: Adam Vetulani 1901-1976, W Służbie Nauki, nr 10, Kraków 2005, s. 13-20.

102 A. Vetulani, Kazimierzowska fundacja krakowskiego studium generale, Sprawozdania Poznańskiego Towarzystwa Przyjaciół Nauk 1962, s. 87-90; t e nż e, Początki wszechnicy krakowskiej, Czasopismo Prawno-Historyczne 16, 1964, s. 9-43, zwł. s. 14-19 
monografii ${ }^{103}$. W kwestii powstania gmachów uniwersyteckich w Kazimierzu wystąpił z zupełnie nową koncepcją. Obalając hipotezę J. Dąbrowskiego o zaprzestaniu wznoszenia kolegium na skutek wylewu (bądź wylewów) Wisły, przyjął, że budowa w Kazimierzu została rozpoczęta w 1362 r., kiedy Kazimierz Wielki dysponował już nieoficjalnym zapewnieniem, że jego prośba dotycząca powołania do życia Studium Generale zostanie rozpatrzona w kurii pozytywnie. Budowę jednak przerwano wraz z nadejściem z Awinionu do Krakowa wiadomości „o roli, jaką przywiązuje kuria papieska do założenia studium generale w miastach znakomitszych"104, ale także na skutek rzekomych zabiegów krakowskich rajców względem utworzenia Uniwersytetu właśnie w Krakowie i to właśnie oni mieli, według Vetulaniego, rozpocząć „zabiegi o zmianę decyzji królewskiej. Czynili to zapewne z jednej strony bezpośrednio u króla oraz pośrednio poprzez jego dworzan, z drugiej zaś - poprzez oddziaływanie na koła kurialne w Awinionie"105. Znając jednak późniejszą niechęć krakowian do instytucji Uniwersytetu, wytykaną im zresztą przez Bartłomieja z Jasła w rozpoczynającej się od wymownych słów zaczerpniętych z Ewangelii (Mt 11,6: Beatus, qui non fuerit scandalizatus in me) mowie, wygłoszonej na pierwszej mszy uniwersyteckiej, prawdopodobnie 4 XII 1390 r., ich osobne zabiegi około fundacji Kazimierzowskiej należałoby uznać raczej za mało prawdopodobne. Według Bartłomieja mieszczanie mieli wręcz gardzić całym Uniwersytetem (contemnunt totam universitatem scolarum), widząc między scholarami jedynie przybyszy łamiących nakazany we środy post, prowadzących nieobyczajne życie czy po prostu grzeszących z ludzkiej słabości ${ }^{106}$.

(toż w języku francuskim: Les origines de l'Université de Cracovie, Acta Poloniae Historica 13, 1966, s. 14-40, zwł. s. 19-24; przedruk w tegoż: Z badań nad kulturą prawniczą w Polsce piastowskiej, Wrocław 1976, s. 184-224). O fundacji krakowskiej na tle porównawczym, zob. te nż e, La fondation des universités dans l'Europe Centrale aux temps du pontificat d'Urbain V, w: La storia del diritto nel quadro delle scienze storiche. Atti del I congresso internazionale della Societa' Italiana di Storia del Diritto, Firenze 1966, s. 361-367; t e n ż e, Papież Urban V wobec nowo zakładanych uniwersytetów środkowoeuropejskich, w: Pastori et magistro, Lublin 1966, s. 203-228; t e n ż e, A pécsi egyetem, valamint a krakkói és bécsi testvéregyetemek alapításának körülményeiröl, w: A pécsi egyetem történetéből, Pécs 1967, s. 21-51; t e n ż e, Vizsgálatok a középkori egyetemi jogi oktatás köréből, w: A 600 éves jogi felsőoktatás történetéből 1367-1967, Pécs 1967 (Studia Iuridica auctoritate Universitatis Pécs publicata 60), s. 141-153; t e n ż e, Die Universitätspolitik Papst Urbans V., w: Ius sacrum. Klaus Mörsdorf zum 60. Geburtstag, München-Paderborn-Wien 1969, s. $140-156$.

103 Te n ż e, Początki najstarszych wszechnic środkowoeuropejskich, Wrocław 1970, zwł. s. $82-91$.

104 Tamże, s. 88.

105 Tamże, s. 90. Dyskusję nad genezą Uniwersytetu oraz jego rzekomą siedzibą w Kazimierzu, włącznie z wypowiedziami A. Vetulaniego, zrelacjonował P. W. K n o 11, Casimir the Great and the University of Cracow, Jahrbuch für Geschichte Osteuropas 16, 1968, s. 238-240.

${ }_{106}$ M. K o w a 1 c z y k, Odnowienie Uniwersytetu Krakowskiego w świetle mów Bartłomieja z Jasła, Małopolskie Studia Historyczne 6, 1963, s. 23-42 (przedruk w: taż, Colligite fragmenta ne pereant... Studia z dziejów Uniwersytetu Krakowskiego w średniowieczu, Historia et Monumenta Universitatis Jagellonicae, t. I, Kraków 2010, s. 94, przyp. 48-49). Nową próbę datacji tego kazania (nigdy niewygłoszonego?) na 5 XII 1400 r. oraz jego interpretacji zaproponował ostatnio Z. Kałuża, Pereat dialectica! O dwu odniesieniach Bartłomieja 
Znamienici autorzy rzadko kiedy przystają na modyfikację własnych ustaleń. A. Vetulani nigdy nie wprowadził do swoich wywodów (w ich późniejszych redakcjach) zasadniczych korekt Zofii Kozłowskiej-Budkowej (1893-1986) ${ }^{107}$, która jako pierwsza sięgnęła do tak zwanego autografu Annales, wyjaśniając, że cały ustęp poświęcony założeniu Uniwersytetu we wsi Bawół oraz staraniach Długosza o założenie kartuzji znalazł się pod 1361 r. na skutek pewnej kombinacji dziejopisa, który wyżej pomieścił notę o początku pontyfikatu Urbana V, ale także błędnie wydatował mandat tego papieża w sprawie założenia arcybiskupstwa (właściwie biskupstwa) we Lwowie na pierwszy rok jego rządów. Co więcej, na tej samej karcie rękopisu znalazła się również informacja o założeniu Uniwersytetu w Pradze, tworząca w pewnym sensie nawiązanie do relacji o fundacji Studium krakowskiego ${ }^{108}$. Wedle Budkowej „właściwy sens tej zapiski to sprawa placu, na którym mógłby stanąć klasztor, sprawa aktualna dla autora w r. 1478 - od niej zaczyna i na niej kończy"109. Z właściwą sobie precyzją cytowana autorka podkreśliła, iż „,przekaz Długosza nie zawiera więc żadnych wiarygodnych wskazówek chronologicznych o początkach Uniwersytetu, natomiast podaje wiarygodną tradycję o budowie gmachów uniwersyteckich na Kazimierzu" ${ }^{110}$. W kolejnym tekście zdecydowanie odrzuciła hipotezę Vetulaniego o możliwości podjęcia budowy już w 1362 r., tłumacząc, ,że król najpierw zamierzał umieścić Uniwersytet w hospicjach u mieszczan, a na kosztowną budowę gmachów zdecydował się dopiero wówczas, gdy się przekonał, że jego przywileje i obiecane salaria nie wystarczają, aby uniwersytet zaczął należycie działać, że studenci są za biedni, aby płacić mieszczanom za hospicja, a mieszczanie nie chcą oddawać kwater za pół darmo - że brak miejsca na lektoria" "111. Po tej wypowiedzi na dwa kolejne dziesięciolecia zapadła niemalże zupełna cisza ${ }^{112}$. Nie udało się także przeprowadzić sondażowych badań archeologicznych, o sfinansowanie których do Senackiej Komisji Jubileuszowej Uniwersytetu Jagiellońskiego jeszcze w kwietniu 1957 r. zwracało się kierownictwo Zakładu Archeologii Polski, planując weryfikację dawniejszych

z Jasła do Gety Witalisa z Blois, Przegląd Tomistyczny 14, 2008, s. 75-86. Pogląd ten należy jednak uznać za bardzo wątpliwy.

107 B. W y r o z u m s k a, O Autorce, w: Z. Kozłowska-Budkowa, Studia (jak w przyp. 2), s. VII-XX.

${ }^{108}$ Zagadnienie to dokładnie omawia M. Z d a n e k, O źródłach Jana Długosza do dziejów fundacji Uniwersytetu Krakowskiego (autorowi dziękuję za udostępnienie przygotowywanego do druku tekstu).

109 Z. K o z łow s k a - B u d k ow a, Kiedy król zaczął budować Uniwersytet na Kazimierzu?, Małopolskie Studia Historyczne 6, 1964, s. 11-15 (przedruk w: taż, Studia [jak w przyp. 2], s. 174).

110 Tamże, s. 176.

111 Ta ż, W sprawie, s. 185.

112 W szkicu adresowanym do szerszego grona czytelników A. G i e y s zt o r, Origines sociale et nationale du corps universitaire de Cracovie aux $\mathrm{XIV}^{\mathrm{e}}$ et $\mathrm{XV}^{\mathrm{e}}$ siècles, w: The Universities in the Late Middle Ages, Leuven 1978, s. 477, jako miejsca odbywania zajęć w Uniwersytecie Kazimierzowskim niejako na równi wymienił wzgórze zamkowe oraz miasto Kazimierz, gdzie król począł wznosić mury kolegium: „Qui enseignait, dans les années 1364-1370, d'abord au château de Cracovie - -, et ensuite dans le quartier Kazimierz où le roi commença à faire élever les murs du collège - - ? Nous ne le savons pas". 
odkryć W. Łuszczkiewicza i S. Tomkowicza na placu Wolnica, jak i propozycji S. Świszczowskiego ${ }^{113}$.

Bez echa, zresztą zupełnie słusznie, przeszedł natomiast nowszy głos urbanisty Bogusława Krasnowolskiego, który bez znajomości kontekstu historycznego (acz opierając rzekomo swój sąd na gruntownej analizie zarówno piętnastowiecznych, jak i nowożytnych przekazów o „,kolegiach”) stwierdził, że występujące w źródłach kazimierskie „kolegia”, nie były bynajmniej budynkami „o charakterze względnie funkcji kolegiów uniwersyteckich, lecz tylko o własności tychże kolegiów, związane z nadaniami na rzecz uniwersytetu, rozwijającymi się po jego reaktywowaniu w r. 1400"114.

Szansy na ustalenie, gdzie rzeczywiście stał gmach Uniwersytetu Kazimierzowskiego, nie wykorzystali też autorzy, którzy dysponowali bądź wypisami źródłowymi z ksiąg miejskich kazimierskich, bądź dostępną od połowy lat dziewięćdziesiątych edycją akt ławniczych kazimierskich z początku XV w. ${ }^{115}$ Jerzy Wyrozumski, nie odwołując się do ustaleń Z. Budkowej, proponował, że wszczęcie budowy kolegium w Kazimierzu mogło wiązać się z królewską supliką do papieża o erygowanie pełnego uniwersytetu. Ponieważ wydział teologiczny musiał mieć strukturę kolegialną, rozpoczęto wznoszenie dla niego gmachu w przykrakowskim Kazimierzu ${ }^{116}$. W syntezie dziejów Krakowa (przygotowywanej w pierwszej połowie lat osiemdziesiątych XX w., ale wydanej drukiem dopiero w 1992 r.) autor ten pisał natomiast, że ,pprzekazy Jana Długosza - - co do chronologii budowy obiektu uniwersyteckiego w Kazimierzu, nie zasługują na wiarę", a budowa w Kazimierzu musiała zostać podjęta po 1364 r. ${ }^{117}$ Z kolei S. Szczur, umiejętnie oddzielając kwestię lokalizacji budowli w Kazimierzu od kwestii funkcjonowania tam Uniwersytetu, przywołał co prawda jedną z zapisek ławniczych, kwitując jednak cały problem stwierdzeniem, że ,pozostałe zapiski są podobne w treści" ${ }^{118}$. Nie wydobył z nich nic również Andrzej Włodarek ${ }^{119}$. Dodać

${ }^{113}$ Kraków, Archiwum Uniwersytetu Jagielońskiego, sygn. Jub. 14: Pismo prof. Rudolfa Jamki do Senackiej Komisji Jubileuszowej z 11 IV 1957 r. Za wskazanie tych informacji składam serdeczne podziękowania dr. Maciejowi Zdankowi.

${ }_{114}$ B. K r a s n o w o 1 s k i, Ulice i place krakowskiego Kazimierza. Z dziejów chrześcijan i Żydów w Polsce, Kraków 1992, s. 179-180. Autor ten nadal podtrzymuje ów kuriozalny sąd, pisząc ,że wzmianki o »kolegiach« [sic] na terenie Kazimierza, pojawiające się w aktach miejskich od początku XV wieku, dotyczą w istocie domów mieszkalnych, z których uniwersytet - po ówczesnym odnowieniu - pobierał czynsze", zob. t e nż e, Bożnice i cmentarze kazimierskiego Miasta Żydowskiego, w: Cracovia Iudaeorum 3D. Katalog wystawy, Kraków 2013, s. 100.

115 Acta scabinalia Cracoviensia 1407-1427. Księga ławnicza kazimierska 1407-1427, wyd. B. Wyrozumska, Kraków 1996 (Fontes Cracovienses 4), nr 548, 947, 1065, 1070, 1297 , 1520, 1545, 1674, 1856, 2035-2036, 2272, 2283, 2492, 2583, 2780.

116 J. W y r o z u m s ki, Kolegia i bursy Uniwersytetu Krakowskiego, w: tenże, Z najstarszych dziejów (jak w przyp. 65), s. 59-61 (wcześniej ten tekst ukazał się w języku francuskim: Les collèges et les internats de l'Université Jagellone aux $\mathrm{XV}^{\mathrm{e}}$ et $\mathrm{XVI}^{\mathrm{e}}$ siècles, w: I collegi universitari in Europa tra il XIV il XVIII secolo, Milano 1991, s. 131-142).

117 Te n ż e, Kraków do schyłku wieków średnich, Kraków 1992 (Dzieje Krakowa, t. I), s. 309-312, cyt. ze s. 311 .

118 S. S z c z u r, Papież, s. 210-216, cyt. s. 211.

119 A. W ł o d a r e k, Architektura średniowiecznych kolegiów i burs Uniwersytetu Krakowskiego, Kraków 2000, s. 16-21, zwł. 19-20. 
wreszcie można, że zapisy z księgi ławniczej kazimierskiej analizował ostatnio także Rafał Witkowski w kontekście lokalizacji klasztoru kartuzów. Ze smutkiem należy jednak stwierdzić, że tych kluczowych dla omawianego zagadnienia nie udało mu się zrozumieć. Wskazywał bowiem, że ,istniała -- wśród mieszkańców Kazimierza utarta tradycja określania pewnego miejsca przy ulicy Tkaczy - - jako collegium, co wydaje się świadczyć jednoznacznie o planach zbudowania (jakiegoś) kolegium uniwersyteckiego przez króla Kazimierza Wielkiego"120. Z przytaczanych przezeń (a szczegółowo analizowanych poniżej) zapisek jednoznacznie wynika bowiem, że ulicą Tkaczy prowadziła droga do kolegium, nie zaś, że samo kolegium stało przy tej ulicy.

Mając na uwadze przedstawione wyżej stanowiska, pozostaje odpowiedzieć na pytanie, jakie informacje względem tytułowego collegium kryją się na kartach piętnastowiecznej księgi ławniczej. Otóż zapisy z niej wydobyte podzielić można przynajmniej na dwie grupy. Do pierwszej będą należały te, w których collegium występuje jako pewien punkt orientacyjny w topografii miasta, w pobliżu którego znajdowały się ogrody. Tytułem przykładu można wskazać, że w 1408 r. Mikołaj Bohemus przeniósł prawo własności ogrodu położonego prope collegium na Jana Schuczlicha. Z kolei połowa ogrodu circa collegium przypadła w 1414 r. Janowi Warzesze. W tym samym roku inną połowę ogrodu prope collegium nabył Grzegorz Golaszowicz ${ }^{121}$. Podobnie formułowane zapisy można by oczywiście mnożyć ${ }^{122}$. Wbrew stanowisku S. Szczura o ich niewielkiej przydatności badawczej, uprawnione jest jednak sformułowanie na tej podstawie dość ważnego wniosku. Skoro przy czy też w pobliżu kolegium znajdowało się wiele ogrodów, nie mogło być raczej ono wybudowane $\mathrm{w}$ jednej z pierzei kazimierskiego rynku. W drugiej grupie znajdują się natomiast te zapiski, które zawierają wskazówki odnośnie do przebiegu drogi do kolegium. Jedne z nich są dość ogólne w treści. Tytułem przykładu wskazać można, iż 28 I 1417 r. znany nam już Jan Schuczlich odstąpił Mikołajowi muratorowi i jego żonie Katarzynie dom położony w pewnym zaułku, jak idzie się do kolegium (in vico, quo itur ad collegium). Z kolei 4 IV 1418 r. niejaki Michał przekazał Mikołajowi Rosniczowi oraz Agnieszce dom wraz z ogrodem położony przy nienazwanej ulicy prowadzącej do kolegium (in platea eundo ad collegium) ${ }^{123}$. W tym kontekście szczególnego znaczenia nabiera zapiska (doskonale znana tak A. Włodarkowi, jak R. Witkowskiemu) dotycząca rezygnacji przeprowadzonej przed sądem gajonym 8 VII 1420 r. Przedmiotem sprawy były należące do dominikanów dom, grunt oraz ogród przy ulicy Tkackiej, eundo in collegium desertum in dextra manu, a zatem idąc w kierunku opuszczonego kolegium po stronie prawej ${ }^{124}$. Ulica Tkacka, zwana także Sukienniczą, zajmująca szczególne miejsce w urbanistycznym planie miasta Kazimierza, prowadziła w kierunku wschodnim od głównego traktu (ulic Stradomskiej i Wielickiej) przecinającego rynek, dochodziła zaś do terenu dawnej wsi Bawół, gdzie z czasem skumulowane zostało osadnictwo żydowskie. Jeśli należąca do braci kaznodziejów parcela znajdowała się po stronie prawej, idąc w kierunku

${ }^{120}$ R. W it k ow s k i, Praedicare manibus, s. 1228-1229.

121 Acta scabinalia, nr 548, 1520, 1545.

122 Tamże, 1674, 2035, 2272.

123 Tamże, nr 1856, 2036.

124 Tamże, nr 2283. 
kolegium, to samo kolegium musiało znajdować się gdzieś u wylotu tej ulicy właśnie po stronie prawej. Tam także stał kościół św. Wawrzyńca ${ }^{125}$. Podobna w treści, aczkolwiek pełniejsza o pewien istotny szczegół, jest zapiska z $25 \mathrm{~V} 1422$ r., kiedy przed sądem kazimierskim stanęli kleryk Janusz wraz ze swoją siostrą Małgorzatą i dokonali przeniesienia prawa własności domu z ogrodem przy ulicy Tkackiej ad desertum collegium eundo in dextra manu retro monasterium Corporis Christi ${ }^{126}$. Tak więc teren pouniwersytecki musiał znajdować się za gruntami należącymi do klasztoru kanoników regularnych Bożego Ciała położonymi między ulicami Tkacką i Świętego Wawrzyńca. W świetle przedstawionych powyżej ustaleń, obszerny plac, na którym stało kolegium, można dziś wyznaczyć od północy ulicą Tkacką (obecnie Józefa), od południa zaś ulicą Świętego Wawrzyńca, jego granicę wschodnią zgodnie z przekazami Długosza i Miechowity określał mur miejski (obecnie jego przebieg wyznacza mniej więcej ulica Dajwór), w pobliżu którego stał kościół św. Wawrzyńca, od zachodu natomiast byłaby to ulica Wąska, oddzielająca układ urbanistyczny Kazimierza od Bawołu (zob. rys. 7). Plac ów był zresztą na tyle duży, by w końcu $\mathrm{XV}$ w. pomieścić na nim zabudowania klasztoru kartuzów ${ }^{127}$. Rację miał zatem ks. A. Buchowski, jak również S. Świszczowski, który szukał terenu pouniwersyteckiego w tzw. mieście żydowskim ${ }^{128}$.

Podsumowując powyższe wywody, można wskazać, iż locus primaevae Universitatis został $\mathrm{z}$ dużym prawdopodobieństwem zidentyfikowany $\mathrm{w}$ topografii Kazimierza. Budynek uniwersytecki pochodzący z czasów Kazimierza Wielkiego, bezspornie wyprowadzony ponad powierzchnię ziemi, aczkolwiek nigdy nie ukończony, jeszcze przez długie lata stanowił dobry punkt orientacyjny w mieście. Nie posiadamy jednak dowodów źródłowych potwierdzających, że już w stuleciu XIV określano go mianem collegium, na pewno zaś wiązano go z instytucją uniwersytetu. Określenie takie przydawano mu w kręgu kancelarii miejskiej od XV w., co miało związek z odnowieniem Studium w Krakowie i utworzeniem Kolegium Króla Władysława. Z czasem, zapewne dla odróżnienia, budynek w Kazimierzu stał się collegium antiquum (kolegium starym), a następnie, najpewniej na skutek systematycznie postępującej degradacji, opuszczonym (desertum) ${ }^{129}$, by w końcu

${ }^{125}$ M. S c h m i d t, M. S t a r z y ń s k i, Nowe miasto tkackie? Szkic do dziejów społeczno-gospodarczych podkrakowskiego Kazimierza, Kwartalnik Historii Kultury Materialnej 63, 2015, s. 19-20; zob. też M. R o ż e k, Nie istniejące kościoły Krakowa, Biuletyn Biblioteki Jagiellońskiej 33, 1983, s. 118-119.

126 Acta scabinalia, nr 2492.

127 O rozwiązaniach architektonicznych kartuzji środkowoeuropejskich obszernie pisze R. W it k o w s k i, Praedicare manibus, s. 172-187 (tam dalsza literatura).

128 Przedstawione wyżej wnioski były już wstępnie prezentowane przeze mnie w pracy: M. S t a r zyńs ki, D. N i e m i e c, Collegium Minus, Kraków 2015, s. 29-31. Zob. także (na podstawie uzyskanych ode mnie informacji): M. Z d a n e k, Uniwersytet na Bawole w Kazimierzu, w: Piękno darowane. Dzieła ofiarowane Uniwersytetowi Jagiellońskiemu w zbiorach Collegium Maius. Katalog wystawy, Kraków 2014, s. 83; S. G ą s i o r o w s k i, W. Kr a w c zu k, Collegium Kazimierzowskie, Kraków 2015, s. 9-11; także M. B a s te r, Zaginione kolegium, Wiedza i Życie 2006, nr 9, s. 68-69.

${ }^{129}$ Po raz pierwszy określono je w ten sposób w 1420 r. (Acta scabinalia, nr 2283). Później np. w 1429 r. (Kraków, Archiwum Narodowe, Acta advocatialia Casimiriensia, rps nr K 451, s. 159) i później. 
tego stulecia przemienić się w zupełną ruinę, sukcesywnie rozbieraną i wreszcie wchłoniętą przez miasto żydowskie.

Dysponując zatem wiedzą, iż podana przez Długosza data fundacji Uniwersytetu w 1361 r. nie wyznacza jej właściwej chronologii, należy odrzucić wszelkie koncepcje, wedle których budowa gmachu w Kazimierzu mogła zostać rozpoczęta przed 1364 r. Wiadomo także, iż rzeczownik locus („miejsce”) występujący w przywileju królewskim z 12 V 1364 r. nie oznacza konkretnego miejsca w mieście (Krakowie), w którym miałyby stanąć budynki uniwersyteckie, ale samą instytucję Uniwersytetu ${ }^{130}$. Przywołując również wyrażone przed ponad stu laty słowa S. Krzyżanowskiego, asumptu do podjęcia w Kazimierzu prac nad budynkiem uniwersyteckim należałoby najpewniej szukać w Pradze, gdzie Karol IV zakupił na potrzeby Uniwersytetu dom, tworząc tym samym pierwsze kolegium (i pierwszą stałą siedzibę Studium), co potwierdza znany dokument cesarski z 30 VII 1366 r. ${ }^{131}$ Data ta wydaje się zatem wyznaczać terminus a quo w historii budynku w Kazimierzu. Podkreślić trzeba, iż król Kazimierz poszedł o krok dalej niż Karol IV, nie kupując domu w Krakowie (co chyba nie stanowiłoby dla monarchy większego wyzwania), ale budując gmach od podstaw na terenie wsi Bawół przekazanej w 1340 r. Nowemu Miastu Krakowskiemu - które nazwał własnym imieniem i zezwolił mu posługiwać się królewskimi znakami władzy ${ }^{132}$. Sam wybór Kazimierza jako nowej siedziby Uniwersytetu należy być może odczytywać w kontekście trwającego od 1362 r. sporu między władzami komunalnymi Krakowa a wpływowym wielkorządcą krakowskim Bodzętą z Kosowic, który dążył wówczas do ograniczenia swobód posiadanych przez miasto, doprowadzając m.in. do wprowadzenia w życie regulacji dotyczącej wyborów do rady miejskiej oraz nieprzestrzegając posiadanych przez gminę przywilejów handlowych ${ }^{133}$. Budowę, stanowiącą krok prowadzący od hospicjów do kolegiów, a zatem do rewitalizacji struktury organizacyjnej Uniwersytetu i przystosowania jej do warunków miejscowych, jak wiadomo rozpoczęto. Ową zmianę miejsca należałoby zatem wiązać ze zmianą ustroju, a więc najpewniej z projektowaną zmianą modelu uposażenia, opartą, wzorem praskim, na beneficjach kościelnych. Nowy monarcha, Ludwik Andegaweński, który stanął w Krakowie w początku listopada 1370 r., nie był jednak zainteresowany, by inicjatywę tę kontynuować. Jak się wydaje, nie miało

${ }^{130}$ K. S t o p k a, Głos w dyskusji, s. 37.

131 Codex diplomaticus Almae Carolo-Ferdinandae Universitatis Pragensis, Monumenta Historica Universitatis Carolo-Ferdinandae Pragensis, t. II, Pragae 1834, nr V; M. S v a to š, Karolinum a kolejní system, w: Dějiny Univerzity Karlovy, t. I, Praha 1995, s. 42-58; W. E. W a g n e r, Universitätsstift und Kollegium in Prag, Wien und Heidelberg. Eine vergleichende Untersuchung spätmittelalterlicher Stiftungen im Spannungsfeld von Herrschaft und Genossenschaft, Berlin 1999 (Europa im Mittelalter 2), s. 37-89; F. Š m a h e 1, Scholae, collegia et bursae universitatis Pragensis. Ein Beitrag zum Wortschatz der mittelalterlichen Universitäten, w: tenże, Die Präger Universität im Mittelalter. Gesammelte Aufsätze. / The Charles University in the Middle Ages. Selected Studies, Leiden-Boston 2007, s. 89 (pierwodruk w: Vocabulaire des collèges universitaires [XIII ${ }^{\mathrm{e}}-\mathrm{XVI}{ }^{\mathrm{e}}$ siècles], Turnhout 1993 [Études sur le vocabulaire intellectuel du moyen âge 6], s. 115-130).

${ }_{132}$ M. S t a r z y ń s k i, Średniowieczny Kazimierz, s. 42-45.

133 Te nż e, Spór o miasto. Kraków w ostatnim dziesięcioleciu panowania Kazimierza Wielkiego, w: Kazimierz - sławny i z czynów Wielki, Kraków 2011, s. 85-95. 
to raczej związku z założeniem przezeń uniwersytetu w Pécsu, ale przede wszystkim z faktem niedokończenia fundacji przez Kazimierza Wielkiego, który nie przekazał zapowiadanego w przywileju z 12 V 1364 r. uposażenia na żupach solnych. Ten prozaiczny powód musiał pociągnąć za sobą przerwanie inwestycji. Kiedy zaś w początku lat dziewięćdziesiątych XIV w. powoli przystępowano do odbudowy Studium w Krakowie, o rozpoczętej w czasach króla Kazimierza budowie gmachu dla Uniwersytetu starano się umyślnie zapomnieć. Nie wspomniał o niej ani razu w swoich mowach Bartłomiej z Jasła. Również po 1400 r. brak jakichkolwiek uchwytnych źródłowo śladów starań Uniwersytetu o dokończenie prac przy kolegium w Kazimierzu. Wyjaśnienie jest dość oczywiste: z nowym fundatorem w osobie króla Władysława wiązało się nowe miejsce w postaci kolegium jego imienia.

Śmierć ostatniego Piasta stanowi zatem pierwszą ważną cezurę w początkowych latach istnienia w Krakowie Studium Generale. Tę przyczynę wskazywał zresztą już Franciszek z Brzegu (ok. 1370-1432/1433), jeden z bardziej znanych teologów wykładających w odnowionym Uniwersytecie, mówiąc w 1414 r. na egzekwiach po śmierci biskupa krakowskiego Piotra Wysza (zmarłego 31 maja), że Uniwersytet, que antea temporibus domini Cazimiri erat inchoata - - post mortem eius interrupta ${ }^{134}$.

\section{BIBLIOGRAFIA}

Baczkowska W., Putanowicz Józef, w: Polski słownik biograficzny, t. XXIX, 1986.

Baczkowski K., Jan Dąbrowski (1890-1965), w: Uniwersytet Jagielloński. Złota księga Wydziału Historycznego, Kraków 2000.

Bandtkie J. S., Dzieje narodu polskiego, t. II, Wrocław 1835.

Barycz H., Radymiński Marcin, w: Polski słownik biograficzny, t. XXX (1987).

Barycz H., Trudne początki (Rzecz o Uniwersytecie Kazimierzowskim), w: tenże, Alma Mater Jagellonica. Studia i szkice z przeszłości Uniwersytetu Krakowskiego, Kraków 1958.

Barycz H., Z zagadek Uniwersytetu Kazimierzowskiego w Krakowie, Przegląd Zachodni 8, 1952.

Barycz H., Z zagadek Uniwersytetu Kazimierzowskiego w Krakowie, Sprawozdania z Czynności i Posiedzeń Polskiej Akademii Umiejętności 52, 1951, nr 9.

Baster M., Zaginione kolegium, Wiedza i Życie 2006, nr 9.

Bąkowski K., Dawne kierunki rzek pod Krakowem, Rocznik Krakowski 5, 1902.

Borowiejska-Birkenmajerowa M., Świszczowski S. (1903-1989), Ochrona Zabytków 43, 1990.

Brandowski A., Założenie Uniwersytetu Krakowskiego w roku 1364 na podstawie dyplomatycznej, Kraków 1872.

Dąbrowski J., Czy Uniwersytet Kazimierzowski działał na Kazimierzu?, Rocznik Biblioteki Polskiej Akademii Nauk w Krakowie 5, 1959 (druk: 1961).

Dużyk J., Treiderowa A., Zagadnienie opieki nad zabytkami w działalności Towarzystwa Naukowego Krakowskiego, Rocznik Biblioteki Polskiej Akademii Nauk w Krakowie 3, 1957 (druk: 1959).

Ekielski E., Miasto Kazimierz i budowle akademickie w tem mieście, Kraków 1869.

Estreicher K., Bibliografia polska XIX stólecia, t. V, XIII, Kraków 1880, 1894.

Gąsiorowski S., Krawczuk W., Collegium Kazimierzowskie, Kraków 2015.

Gedl M., Józef Łepkowski (1826-1894), w: Uniwersytet Jagielloński. Złota księga Wydziału Historycznego, Kraków 2000.

${ }^{134}$ M. K o w a l c z y k, Krakowskie mowy uniwersyteckie z pierwszej połowy XV wieku, Wrocław 1970, s. 131, przyp. 14. 
Gieysztor A., Origines sociale et nationale du corps universitaire de Cracovie aux XIV et XV siècles, w: The Universities in the Late Middle Ages, Leuven 1978.

Gryglewski R. W., Józef Oettinger (1818-1895), w: Uczeni żydowskiego pochodzenia we współczesnych dziejach Uniwersytetu Jagiellońskiego, Kraków 2014.

Kałuża Z., Pereat dialectica! O dwu odniesieniach Bartłomieja z Jasła do Gety Witalisa z Blois, Przegląd Tomistyczny 14, 2008, s. 75-86

Knoll P. W., Casimir the Great and the University of Cracow, Jahrbuch für Geschichte Osteuropas 16, 1968.

Konieczna W., Początki Kazimierza (do r. 1419), w: Studia nad przedmieściami Krakowa, Kraków 1938 (Biblioteka Krakowska 94).

Kowalczyk M., Krakowskie mowy uniwersyteckie z pierwszej połowy XV wieku, Wrocław 1970.

Kowalczyk M., Odnowienie Uniwersytetu Krakowskiego w świetle mów Bartłomieja z Jasła, Małopolskie Studia Historyczne 6, 1963.

Kozłowska-Budkowa Z., Kiedy król zaczął budować Uniwersytet na Kazimierzu?, Małopolskie Studia Historyczne 6, 1964.

Kozłowska-Budkowa Z., La fondation de l'Université de Cracovie, en 1364, et son rôle dans le développement de la civilisation en Pologne, w: Les Universités Européennes du XIV e au XVIII ${ }^{\mathrm{e}}$ Siècle. Aspects et Problèmes, Genève 1967.

Kozłowska-Budkowa Z., W sprawie Uniwersytetu Kazimierzowskiego (przegląd nowych ustaleń, dyskusji i hipotez), Studia Historyczne 12, 1969.

Kozłowska-Budkowa Z., Założenie Uniwersytetu w Krakowie w roku 1364 i jego rola w rozwoju kultury w Polsce, w: taż, Studia z dziejów kultury średniowiecznego Krakowa, Kraków 2015 (Biblioteka Krakowska 161).

Kras J., Łopuszański B., Muczkowski Józef, w: Polski słownik biograficzny, t. XXII (1977).

Krasnowolski B., Bożnica Wysoka na krakowskim Kazimierzu, Krzysztofory. Zeszyty Naukowe Muzeum Historycznego Miasta Krakowa 21, 2002.

Krasnowolski B., Bożnice i cmentarze kazimierskiego Miasta Żydowskiego, w: Cracovia Iudaeorum 3D. Katalog wystawy, Kraków 2013.

Krasnowolski B., Ulice i place krakowskiego Kazimierza. Z dziejów chrześcijan i Żydów w Polsce, Kraków 1992.

Krzyżanowski S., Poselstwo Kazimierza Wielkiego do Awinionu i pierwsze uniwersyteckie przywileje, Rocznik Krakowski 4, 1900.

Łatak K. CRL, Ksiądz Stefan Ranatowicz (1617-1694). Barkowy kronikarz i pisarz klasztorny, Kraków 2010.

Łepkowski J., O zabytkach Kruszwicy, Gniezna i Krakowa oraz Trzemeszna, Rogoźna, Kcyni, Dobieszewka, Gołańczy, Żnina, Gąsawy, Pakości, Kościelca, Inowrocławia, Strzelna i Mogilna sprawozdania i studia, Kraków 1866.

Łuszczkiewicz W., Sprawozdanie z wypadku poszukiwań Komissji, wyznaczonej z grona Towarzystwa Nauk. Krak. celem odszukania miejsca i zabytków budowlanych Uniwersytetu założonego przez Kazimierza Wielkiego, Rocznik Towarzystwa Naukowego Krakowskiego 34, 1866.

Markowski M, Uniwersytet Krakowski w kontekście środkowoeuropejskim późnego średniowiecza i wczesnej nowożytności, Olecko 2005 (Episteme 40).

Morawski K., Historia Uniwersytetu Jagiellońskiego. Średnie wieki i Odrodzenie ze wstępem o Uniwersytecie Kazimierza Wielkiego, t. I, Kraków 1900.

Muczkowski J., Wiadomość o założeniu Uniwersytetu Krakowskiego, Rocznik Towarzystwa Naukowego Krakowskiego z Uniwersytetem Jagiellońskim Złączonego 19, 1849

Niemiec D., Średniowieczna geneza Starej Synagogi z krakowskiego Kazimierza, w: Ostoja tradycji. Katalog wystawy, Kraków 2016.

Ogrodziński W., Brandowski Roch Alfred, w: Polski słownik biograficzny, t. II (1936).

Perkowska U., Jubileusze Uniwersytetu Jagiellońskiego, Kraków 2000 (Biblioteka Krakowska 140). 
Płaza S., Adam Vetulani - wydawca źródeł oraz badacz ustroju i prawa polskiego, w: Adam Vetulani 1901-1976, W Służbie Nauki, nr 10, Kraków 2005.

Rederowa D., Stachowska K., Ośrodek naukowy krakowski w świetle materiałów Towarzystwa Naukowego Krakowskiego 1841-1871. Wybór źródeł, Rocznik Biblioteki Polskiej Akademii Nauk w Krakowie 2, 1956 (druk: 1959).

Remer J., Stanisław Tomkowicz. Sylweta konserwatora, Ochrona Zabytków Sztuki 1, 19301931.

Rożek M., Nie istniejące kościoły Krakowa, Biuletyn Biblioteki Jagiellońskiej 33, 1983.

Rzepińska M., Na styku pedagogiki i historii sztuki. Ze studiów na Władysławem Łuszczkiewiczem, w: Symbolae historiae artium. Studia z historii sztuki Lechowi Kalinowskiemu dedykowane, Warszawa 1986.

Schmidt M., Starzyński M., Nowe miasto tkackie? Szkic do dziejów społeczno-gospodarczych podkrakowskiego Kazimierza, Kwartalnik Historii Kultury Materialnej 63, 2015.

Sikora F., O fundacji kartuskiej Jana Długosza, Kwartalnik Historyczny 80, 1973.

Słownik historyczno-geograficzny województwa krakowskiego w średniowieczu, cz. I, z. 1, Wrocław 1980.

Sołtykowicz J., O stanie Akademii Krakowskiej od założenia jej w roku 1347, aż do teraźniejszego czasu, krótki wykład historyczny, Kraków 1810.

Sondel J., Przywileje fundacyjne Uniwersytetu Jagiellońskiego oraz przywilej nadania szlachectwa jego profesorom (z historyczno-prawnym komentarzem), Kraków 2015.

Starzyński M., Spór o miasto. Kraków w ostatnim dziesięcioleciu panowania Kazimierza Wielkiego, w: Kazimierz - sławny i z czynów Wielki, Kraków 2011.

Starzyński M., Średniowieczny Kazimierz, jego ustrój i kancelaria, Kraków 2015.

Starzyński M., Niemiec D., Collegium Minus, Kraków 2015.

Stopka K., Głos w dyskusji nad fundacją Uniwersytetu w Krakowie, Rocznik Krakowski 71, 2005.

Stopka K., Henryk Barycz jako dziejopis Akademii Krakowskiej, w: Henryk Barycz 19011994, W Służbie Nauki, nr 9, Kraków 2004.

Svatoš M., Karolinum a kolejní system, w: Dějiny Univerzity Karlovy, t. I, Praha 1995.

Szczur S., Papież Urban V i powstanie Uniwersytetu w Krakowie w 1364 r., Kraków 1999.

Świszczowski S., Miasto Kazimierz od Krakowem, Kraków 1981.

Świszczowski S., Miasto żydowskie na Kazimierzu w świetle nowych badań, Biuletyn Krakowski 2, 1960.

Świszczowski S., Uniwersytet Kazimierza Wielkiego w Kazimierzu, Sprawozdania z Czynności i Posiedzeń Polskiej Akademii Umiejętności 52, 1951, nr 2.

Šmahel F., Scholae, collegia et bursae universitatis Pragensis. Ein Beitrag zum Wortschatz der mittelalterlichen Universitäten, w: tenże, Die Präger Universität im Mittelalter. Gesammelte Aufsätze. / The Charles University in the Middle Ages. Selected Studies, Leiden-Boston 2007.

Tomkowicz S., Ślady Uniwersytetu Kazimierzowskiego?, Rocznik Krakowski 5, 1902.

Tyrowicz M., Ekielski Eustachy Wojciech, w: Polski słownik biograficzny, t. VI (1948).

Uljasz A., Jerzy Samuel Bandtkie (1768-1835). Uczony, pedagog i pracownik książki polskiej, Annales Universitatis Paedagogicae Cracoviensis 104, 2011, Studia ad Bibliothecarum Scientiam Pertinentia 9.

Uruszczak W., Powstanie Uniwersytetu w Krakowie w 1364 roku, Czasopismo-Prawno Historyczne 64, 2014.

Vetulani A., A pécsi egyetem, valamint a krakkói és bécsi testvéregyetemek alapításának körülményeiről, w: A pécsi egyetem történetéből, Pécs 1967.

Vetulani A., Die Universitätspolitik Papst Urbans V., w: Ius sacrum. Klaus Mörsdorf zum 60. Geburtstag, München-Paderborn-Wien 1969.

Vetulani A., Kazimierzowska fundacja krakowskiego studium generale, Sprawozdania Poznańskiego Towarzystwa Przyjaciół Nauk 1962. 
Vetulani A., La fondation des universités dans l'Europe Centrale aux temps du pontificat d'Urbain V, w: La storia del diritto nel quadro delle scienze storiche. Atti del I congresso internazionale della Societa' Italiana di Storia del Diritto, Firenze 1966.

Vetulani A., Les origines de l'Université de Cracovie, Acta Poloniae Historica 13, 1966.

Vetulani A., Papież Urban V wobec nowo zakładanych uniwersytetów środkowoeuropejskich, w: Pastori et magistro, Lublin 1966.

Vetulani A., Początki najstarszych wszechnic środkowoeuropejskich, Wrocław 1970.

Vetulani A., Początki wszechnicy krakowskiej, Czasopismo Prawno-Historyczne 16, 1964.

Vetulani A., Vizsgálatok a középkori egyetemi jogi oktatás köréből, w: A 600 éves jogi felsőoktatás történetéből 1367-1967, Pécs 1967 (Studia Iuridica auctoritate Universitatis Pécs publicata 60).

Wagner W. E., Universitätsstift und Kollegium in Prag, Wien und Heidelberg. Eine vergleichende Untersuchung spätmittelalterlicher Stiftungen im Spannungsfeld von Herrschaft und Genossenschaft, Berlin 1999 (Europa im Mittelalter 2).

Wereszycka H., Orman-Michta E., Sołtykowicz (Sołtykiewicz) Józef, w: Polski słownik biograficzny, t. XL (2000-2001).

Witkowski R., Praedicare manibus. Zakon Kartuzów w Europie Środkowej od początku XIV do połowy XVI wieku, Salzburg 2011 (Analecta Cartusiana 285/2).

Włodarek A., Architektura średniowiecznych kolegiów i burs Uniwersytetu Krakowskiego, Kraków 2000.

Wyrozumska B., O Autorce, w: Z. Kozłowska-Budkowa, Studia z dziejów kultury średniowiecznego Krakowa, Kraków 2015 (Biblioteka Krakowska 161).

Wyrozumska B., Stanisław Krzyżanowski (1865-1917), w: Mediewiści, Poznań 2011.

Wyrozumski J., Kolegia i bursy Uniwersytetu Krakowskiego, w: tenże, Z najstarszych dziejów Uniwersytetu Krakowskiego. Szkice, Kraków 1996.

Wyrozumski J., Kraków do schyłku wieków średnich, Kraków 1992 (Dzieje Krakowa, t. I)

Wyrozumski J., L'università bolognese e lo Studio generale cracoviano di Casimiro il Grande, w: Commentationes historicae Almae Matri Studiorum Bononiensi novem saecula feliciter celebranti ab Universitate Jagellonica Cracoviensi oblatae, Kraków 1988.

Wyrozumski J., Les collèges et les internats de l'Université Jagellone aux XV et XVI ${ }^{\mathrm{e}}$ siècles, w: I collegi universitari in Europa tra il XIV il XVIII secolo, Milano 1991.

Wyrozumski J., Uniwersytet Krakowski a Uniwersytet Boloński, w: tenże, Z najstarszych dziejów Uniwersytetu Krakowskiego. Szkice, Kraków 1996.

Zdanek M., O źródłach Jana Długosza do dziejów fundacji Uniwersytetu Krakowskiego (w druku).

Zdanek M., Uniwersytet Krakowski wobec własnej przeszłości w XV i na początku XVI wieku. Stan i perspektywy badań, w: Felix indiget amicis. Studia z dziejów kultury duchowej i intelektualnej średniowiecza ofiarowane Profesorowi Krzysztofowi Ożogowi, Kraków 2016.

Zdanek M., Uniwersytet na Bawole w Kazimierzu, w: Piękno darowane. Dzieła ofiarowane Uniwersytetowi Jagiellońskiemu w zbiorach Collegium Maius. Katalog wystawy, Kraków 2014.

\section{Collegium desertum - die unvollendete Universitätsstiftung Kasimirs des Großen}

\section{Zusammenfassung}

Der vorliegende Beitrag stellt den Versuch dar, die bisherigen Forschungsmeinungen zur Lage und zum Zeitpunkt des Baubeginns des ersten festen Sitzes der Universität König Kasimirs des Großen einer Revision zu unterziehen. Der Autor lokalisiert das alte Universitätsgelände in der Stadt Kasimir bei Krakau, und zwar auf einem Areal, das von den Straßen Tkacka (heute Józefa), Wąska, Św. Wawrzyńca und der Stadtmauer eingegrenzt war (dem ungefähren 
Mauerverlauf entspricht heute der Verlauf der Straße Dajwór). Den Anlaß zur Entstehung dieser Einrichtung gab wohl die Stiftung des Collegium Carolinum in Prag 1366. Das unvollendete Universitätsgebäude wurde seit Anfang des 15. Jahrhunderts als collegium bezeichnet, was im Zusammenhang mit der Neugründung der Universität in Krakau und der Stiftung des Kollegs König Wladislaus' stand (1400). Mit der Zeit wurde das ältere Gebäude in Kasimir - wohl um es von dem neueren zu unterscheiden - als collegium antiquum und später als collegium desertum bezeichnet, um gegen Ende des Jahrhunderts vollständig zur Ruine zu werden und schließlich gänzlich in der jüdischen Stadt aufzugehen. Die Stiftung in Krakau stand in Verbindung mit Bemühungen um die Umstellung des Verfassung (vom hospitium zum collegium) und der Ausstattung der Hochschule, das von da an entsprechend dem Prager Modell auf kirchlichen Benefizien beruhte. Das Projekt wurde vom Tod König Kasimirs (1370) unterbrochen, dem es nicht mehr gegönnt war, seiner Universität die in Aussicht gestellten Einkünfte aus den Salzbergwerken zu übertragen. Sein Nachfolger Ludwig von Anjou war an der Fortführung dieser Initiative nicht mehr interessiert, so daß bei der Neugründung der Universität im Jahre 1400 der Stifter Wladislaus Jagiello ein neues Kolleg errichten ließ, das auch seinen Namen trug.

Übersetzt von Waldemar Könighaus

\title{
Collegium desertum - unfinished university foundation of Kazimierz the Great
}

\author{
Abstract
}

The paper attempts a revision of current historiographic opinion on the localisation and the time of undertaking work on the first permanent premises of the University of Kazimierz the Great. The author outlines the university area in the town of Kazimierz, marked by the streets Tkacka (today Józefa), Wąska, Świętego Wawrzyńca and the city walls (now roughly equivalent to Dajwór Street). The decision was probably inspired by the foundation of Collegium Carolinum in Prague in 1366. The investment in Cracow was related to the attempted changing of the organisational model of the university (from hospitial to collegial) and the model of funding, based - as in Prague - on church benefices. The undertaking was interrupted by the death of King Kazimierz (1370).

Translated by Rafat T. Prinke

dr hab. Marcin Starzyński, Zakład Nauk Pomocniczych Historii, Instytut Historii, Uniwersytet Jagielloński, ul. Gołębia 13, 31-007 Kraków, e-mail: starzynski@ymail.com 


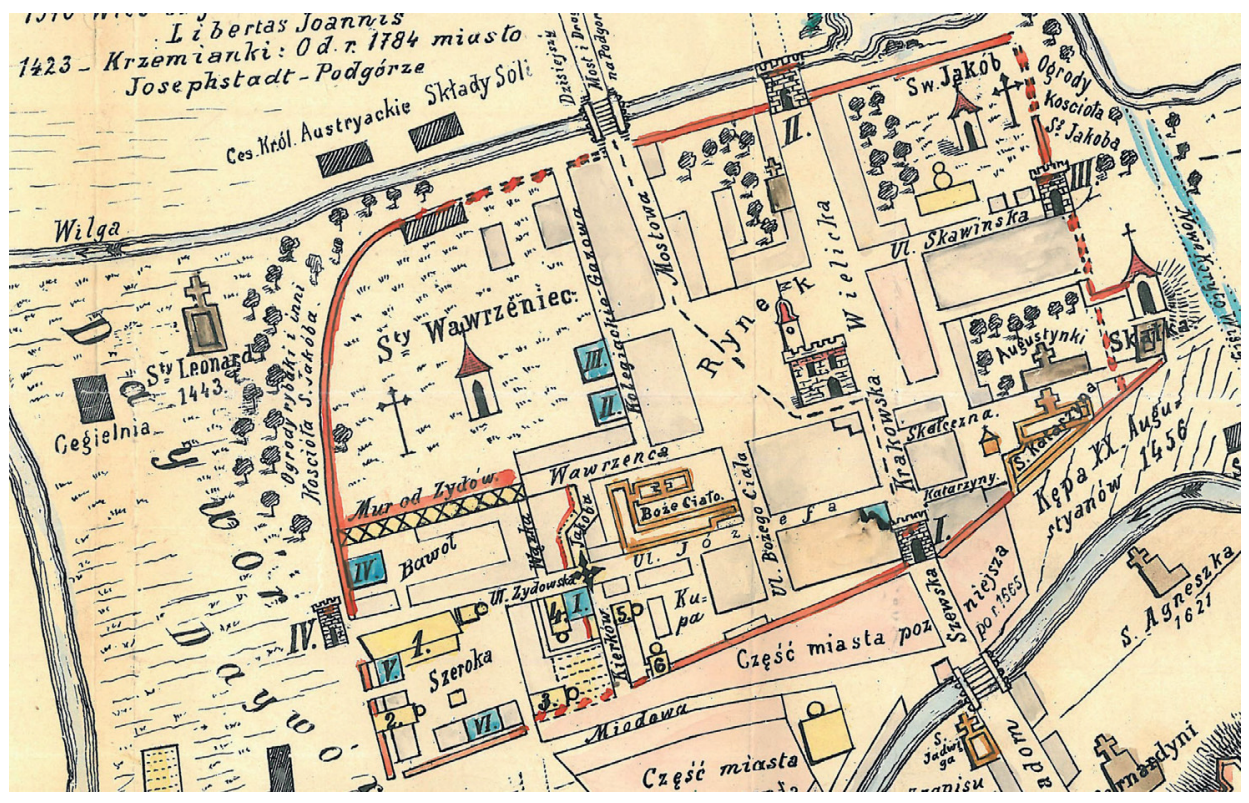

Rys. 1. Plan miasta Kazimierza dla zrozumienia stanu w jakim był prawdopodobnie za Kazimierza Wielkiego, opr. E. Ekielski (według: tenże, Miasto Kazimierz i budowle akademickie w tem mieście, Kraków 1869); obiekty identyfikowane w XIX w. z zabudowaniami uniwersyteckimi: nr I - dom u zbiegu ulic Kierków (obecnie Jakuba) oraz Józefa (Ekielski); nr II-III - domy przy ulicy Gazowej (Łuszczkiewicz), V-VI - domy przy ulicy Szerokiej (Łepkowski, Łuszczkiewicz); nr 4 - Synagoga Wysoka; Mur od Żydów - mur w północnej części cmentarza kościoła św. Wawrzyńca oddzielający Kazimierz chrześcijański od żydowskiego.



Rys. 2. Teren pouniwersytecki według ustaleń W. Łuszczkiewicza (1866) oznaczony na planie katastralnym miasta z 1848 r. (według: Atlas historyczny miast polskich, t. V, z. 1: Kraków, Kraków 2007, nr 1.1), opr. graf. D. Niemiec. 


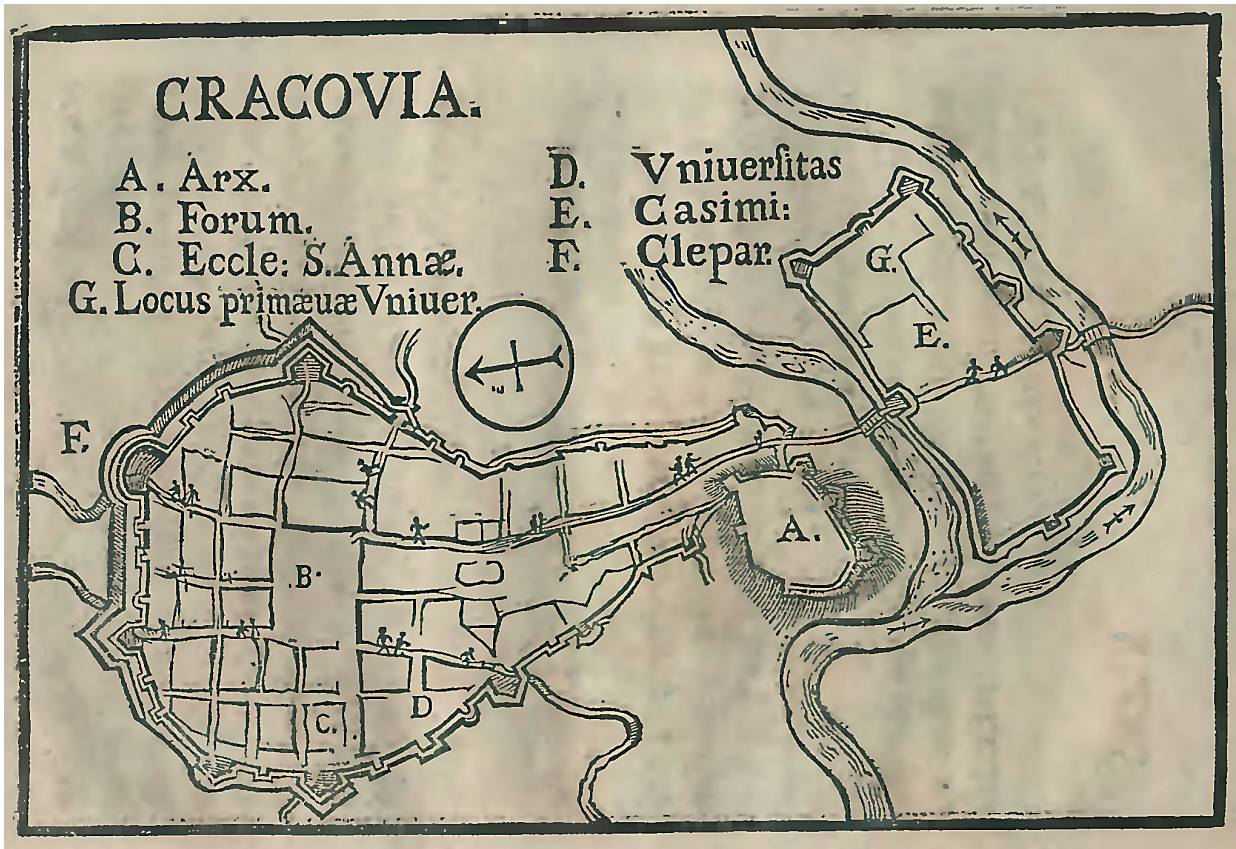

Rys. 3. Plan Krakowa i Kazimierza z oznaczeniem locum primaevae Universitatis (według: A. S. Buchowski, Gloria Domini, Cracoviae 1703, plan na k. 4r, foliacja własna).

Rys. 4. Plan południowo-wschodniego naroża dawnego rynku kazimierskiego (placu Wolnica) z zaznaczonymi gotyckimi murami odsłoniętymi w 1868 r., identyfikowanymi jako pozostałości kolegium uniwersyteckiego (według: A. Brandowski, Założenie Uniwersytetu Krakowskiego w roku 1364 na podstawie dyplomatycznej, Kraków 1872 , rys. po s. 262).

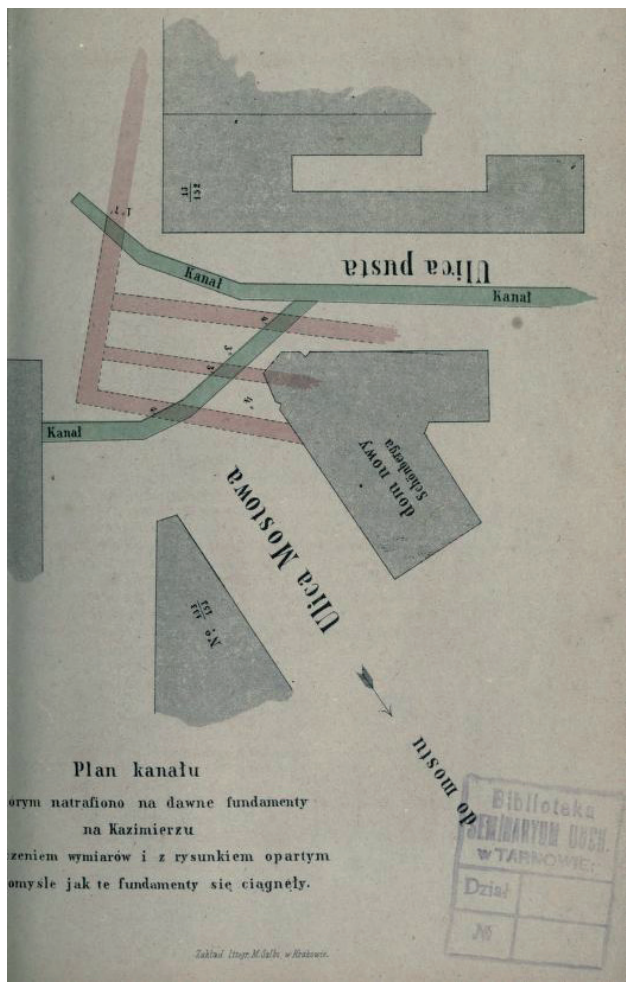




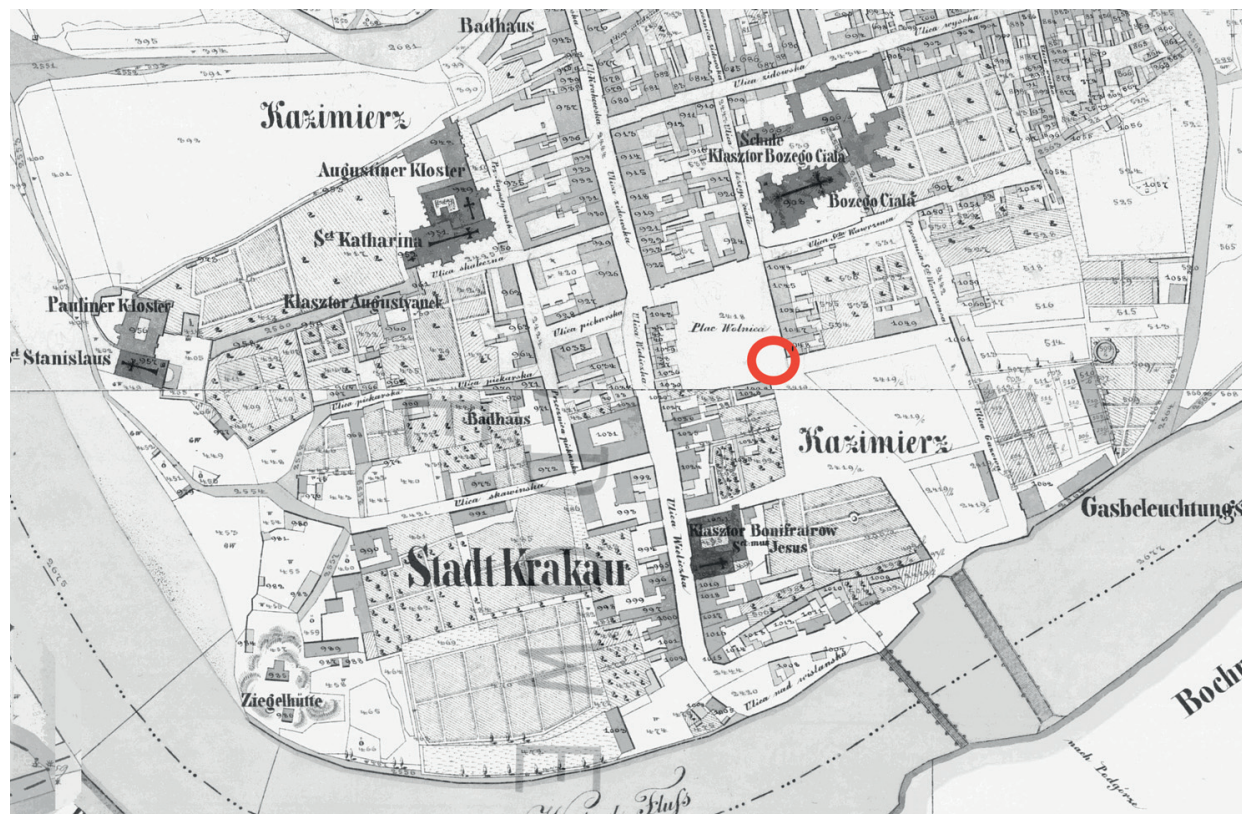

Rys. 5. Teren pouniwersytecki według ustaleń W. Łuszczkiewicza (1868) oznaczony na planie katastralnym miasta z 1848 r., opr. graf. D. Niemiec.

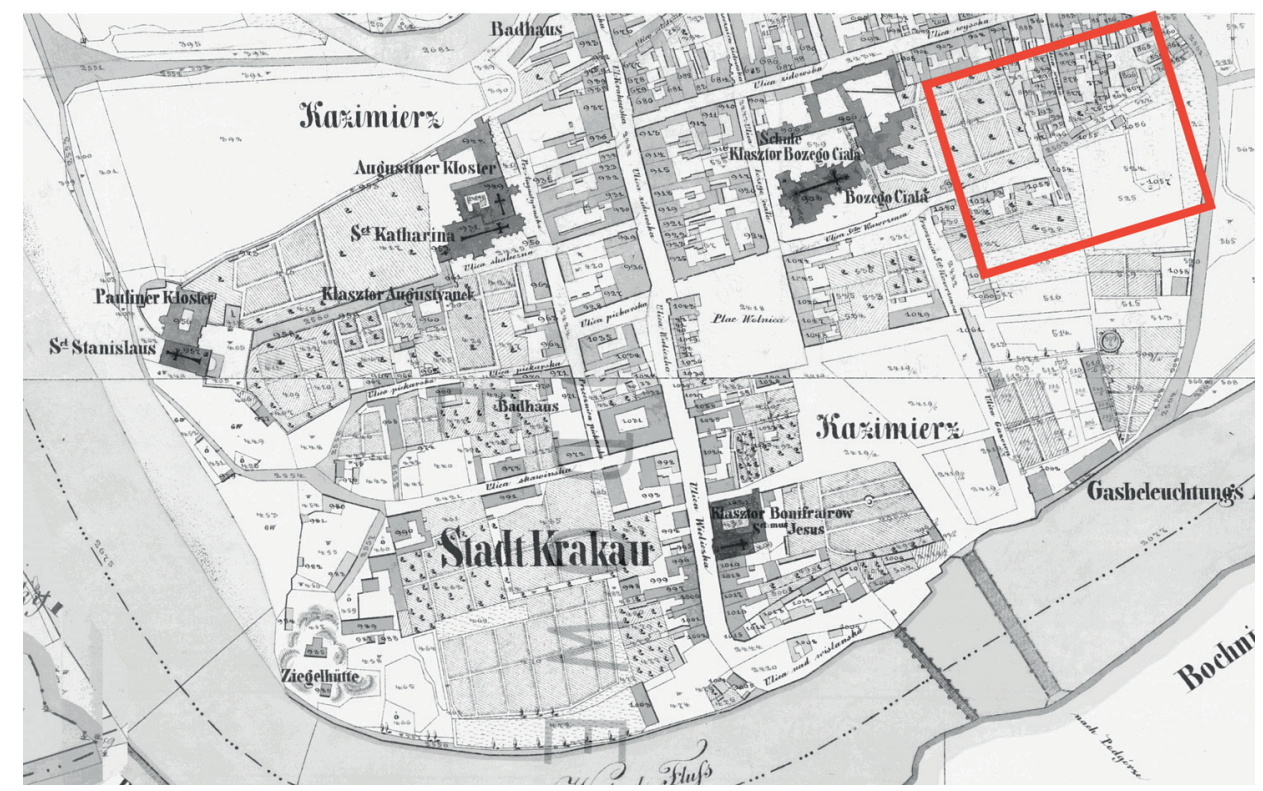

Rys. 6. Teren pouniwersytecki według ustaleń S. Tomkowicza (1901) oznaczony na planie katastralnym miasta z 1848 r., opr. graf. D. Niemiec. 


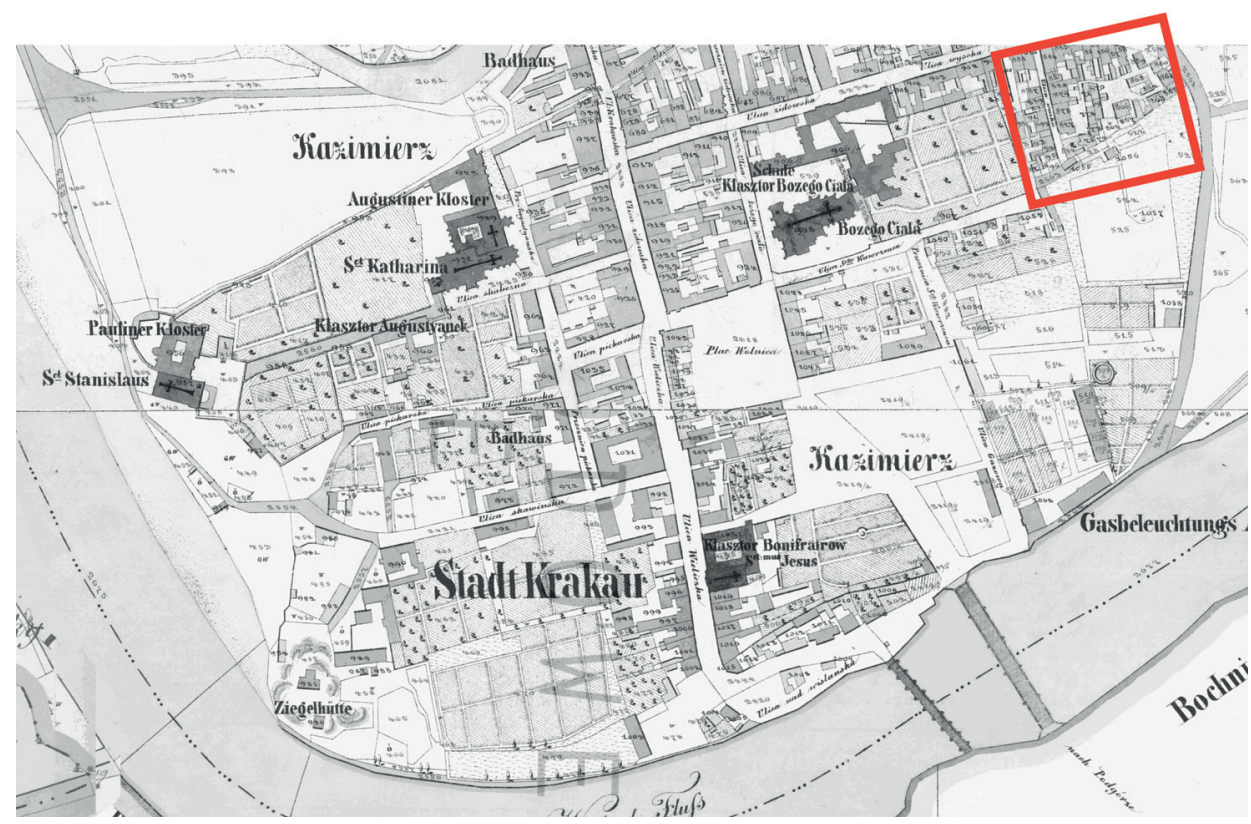

Rys. 7. Teren pouniwersytecki według ustaleń M. Starzyńskiego (2016) oznaczony na planie katastralnym miasta z 1848 r., opr. graf. D. Niemiec. 